\title{
Produced Water Treatment with Conventional Adsorbents and MOF as an Alternative: A Review
}

\author{
Humaira Gul Zaman ${ }^{1}$, Lavania Baloo ${ }^{1, *}$, Rajashekhar Pendyala ${ }^{2}$ (D) Pradeep Kumar Singa ${ }^{3}$ (D), \\ Suhaib Umer Ilyas ${ }^{4}$ (D) and Shamsul Rahman Mohamed Kutty ${ }^{1}$ \\ 1 Civil and Environmental Engineering Department, Universiti Teknologi PETRONAS, \\ Seri Iskandar 32610, Malaysia; humaira_19001707@utp.edu.my (H.G.Z.); \\ shamsulrahman@utp.edu.my (S.R.M.K.) \\ 2 Chemical Engineering Department, Universiti Teknologi PETRONAS, Seri Iskandar 32610, Malaysia; \\ raj.pendyala@gmail.com \\ 3 Department of Civil Engineering, Guru Nanak Dev Engineering College Bidar, Bidar 585403, India; \\ pmsinga@gmail.com \\ 4 Institute of Hydrocarbon Recovery, Universiti Teknologi PETRONAS, Seri Iskandar 32610, Malaysia; \\ suhaibui@outlook.com \\ * Correspondence: lavania.baloo@utp.edu.my
}

check for updates

Citation: Gul Zaman, H.; Baloo, L.; Pendyala, R.; Singa, P.K.; Ilyas, S.U.; Kutty, S.R.M. Produced Water Treatment with Conventional Adsorbents and MOF as an Alternative: A Review. Materials 2021, 14, 7607. https://doi.org/10.3390/ ma14247607

Academic Editors: Roman Fediuk and Mujahid Ali

Received: 7 November 2021

Accepted: 24 November 2021

Published: 10 December 2021

Publisher's Note: MDPI stays neutral with regard to jurisdictional claims in published maps and institutional affiliations.

Copyright: (c) 2021 by the authors. Licensee MDPI, Basel, Switzerland. This article is an open access article distributed under the terms and conditions of the Creative Commons Attribution (CC BY) license (https:/ / creativecommons.org/licenses/by/ $4.0 /)$.
Abstract: A large volume of produced water (PW) has been produced as a result of extensive industrialization and rising energy demands. PW comprises organic and inorganic pollutants, such as oil, heavy metals, aliphatic hydrocarbons, and radioactive materials. The increase in PW volume globally may result in irreversible environmental damage due to the pollutants' complex nature. Several conventional treatment methods, including physical, chemical, and biological methods, are available for produced water treatment that can reduce the environmental damages. Studies have shown that adsorption is a useful technique for PW treatment and may be more effective than conventional techniques. However, the application of adsorption when treating PW is not well recorded. In the current review, the removal efficiencies of adsorbents in PW treatment are critically analyzed. An overview is provided on the merits and demerits of the adsorption techniques, focusing on overall water composition, regulatory discharge limits, and the hazardous effects of the pollutants. Moreover, this review highlights a potential alternative to conventional technologies, namely, porous adsorbent materials known as metal-organic frameworks (MOFs), demonstrating their significance and efficiency in removing contaminants. This study suggests ways to overcome the existing limitations of conventional adsorbents, which include low surface area and issues with reuse and regeneration. Moreover, it is concluded that there is a need to develop highly porous, efficient, eco-friendly, cost-effective, mechanically stable, and sustainable MOF hybrids for produced water treatment.

Keywords: adsorbents; adsorption; metal-organic frameworks (MOFs); produced water; sustainability; water treatment

\section{Introduction}

Oil and gas reserves play an essential role in the global economy, and resource use has been intensified over the years to meet rising energy demands [1]. Oil and gas industries produce a significant amount of wastewater in large quantities, bringing it to the surface as part of the oil production process. This wastewater is generally termed produced water (PW). It is polluted with heavily immiscible oil, organics, heavy metals, salts, suspended solids, and radioactive components [2]. From 1990 to 2015, PW production increased from less than 30,000,000 barrels per day to approximately 100,000,000 barrels per day [3]. Worldwide, day-to-day fuel consumption is expected to increase from 85 million barrels in 2006 to 106.6 million barrels by 2030 [4]. The oil and gas production activities have produced a vast amount of PW, with oil generating a greater upward flow of PW compared 
to gas wells [5]. It has been estimated that offshore oil and gas fields generate $39.5 \mathrm{Mm}^{3} /$ day of PW [6]. Globally, the volume of PW production is approximately $200 \mathrm{Mbbl} /$ day, which is three times more than oil production [7].

Furthermore, the PW volume in depleted fields could reach as high as $98 \%$ of the remaining content, with only $2 \%$ of what is recovered being suitable for fossil fuel production [8]. Untreated PW discharge into the ecosystem may have a disastrous effect on the environment due to the high levels of hazardous contaminants. Therefore, the oil and gas industries must treat PW to protect the environment and human wellbeing.

Several methods of treating PW have been investigated in the literature, some of which involve using physicochemical, biological, and membrane technologies [2,9-12]. Conventional treatment technologies, such as physical methods, require a long retention time, a vast land area, high initial costs, and secondary pollutant production. On the other hand, chemical methods require high chemical inputs and uneconomical operational procedures. Moreover, the secondary pollutants, in the form of sludge, need further treatment, increasing the treatment costs. Physicochemical treatments only transfer the contaminants from one medium to another without complete degradation and mineralization. The literature suggests that conventional treatment methods have low remediation efficiencies as standalone technologies [13]. For instance, membrane technology can only perform better when integrated with biological processes. It also has several disadvantages, such as high energy pressure requirements, membrane fouling, and high maintenance costs. The drawbacks limit these methods' applicability at the commercial level because industries require efficient, economical, and environmentally friendly treatment processes. The traditional techniques reinject waste streams into the well, discharge it directly, or reuse waste in a thermal loop. Thus, there is a need for alternative methods and technologies for PW treatment. Adsorption is one of the most attractive environmental remediation techniques due to its design simplicity, its low operational cost, and its minimization of chemical or biological sludges. It can be applied without high temperature or pressure requirements and may remove harmful chemicals and pollutants from the environment [14]. In adsorption mechanisms, a solid surface comes into contact with liquids and tends to accumulate a surface layer of solute molecules, which provides complex and compelling pollutant-reduction abilities. It is reported that adsorption could easily remove $80 \%$ of the heavy metals from PW and be capable of restoring $100 \%$ of water [10].

However, adsorption is still being utilized merely as a unit process or polishing step in the treatment train. Yet strict water quality parameters can be met efficiently through adsorption. The most important advantages of using the adsorption process are its operational ease, the regeneration of the adsorbent, and the fact that is has no additional chemical requirements. Various adsorbent materials have been studied for use in adsorption methods, such as nanomaterials, nanocomposites, nanoparticles, clays, biopolymers, metal-organic frameworks (MOFs), and zeolites [15-18]. In the last decade, MOFs, as a novel type of exceptionally crystalline porous materials that are assembled by connecting ligands with metal ions or metal ion clusters, have become the focus of a significant amount of research $[17,19]$. MOFs have remarkably large surface areas, porous sizes, shapes, and structures. Furthermore, because the functional groups of these materials influence their adsorption characteristics, MOFs can be functionalized, making them promising adsorbents [17].

This review paper focuses on evaluating the feasibility of the adsorption process, given that it is one of the most promising techniques for removing pollutants. However, to the best of our knowledge, there have been no comprehensive reviews that have holistically evaluated the efficiency and suitability of different conventional adsorbent methods when used with PW, nor any which have discussed developments in the creation of highly porous, reusable adsorbents. Future opportunities to use modern, highly porous, reusable adsorbents, which may be an alternative to conventional ones, are highlighted. Currently, a limited amount of literature is available on the application of adsorption techniques for PW treatment. This review critically analyzes the suitability and limitations of different 
available adsorbents for PW treatment. Recent progress and developments in applying MOF adsorbents in PW treatment are emphasized. Future perspectives on PW treatment using eco-friendly, cost-effective, and reusable adsorbents are pointed out, which some believe can decrease our dependence on limited freshwater resources.

\section{Composition of Produced Water}

Water accounts for the majority of the composition of PW. Its composition varies considerably based on the geographical location, reservoir characteristics, hydrocarbon production, and minerals in the water-bearing geological formation [20]. PW consists of organics, inorganics, production chemicals, and transformation compounds, which are outlined in Table 1 [21]. The organic compounds in PW are oil and grease, as well as aromatic compounds, including benzene, toluene, ethylbenzene, and xylenes (BTEX). BTEX have a non-polar aliphatic character and interact with other substances through weak dispersive forces [22]. PW may contain critical organic pollutants, such as halogenated aromatic compounds, chloroform, naphthalene, phenanthrene, dibenzothiophene (NPD), polyaromatic hydrocarbons (PAHs), phenols, and trichloroethylene.

Table 1. Composition of produced water [3].

\begin{tabular}{ccc}
\hline Parameter & Units & Ranges \\
\hline $\mathrm{pH}$ & - & $4.3-10$ \\
\hline Total Dissolved Solids & $\mathrm{mg} / \mathrm{L}$ & $100-400,000$ \\
\hline Total Suspended Solids & $\mathrm{mg} / \mathrm{L}$ & $1.2-1000$ \\
\hline Chemical Oxygen Demand & $\mathrm{mg} / \mathrm{L}$ & $1220-2600$ \\
\hline Total Organic Carbon & - & 1500 \\
\hline Salinity & $\mathrm{mg} / \mathrm{L}$ & $5000-300,000$ \\
\hline Conductivity & $\mu \mathrm{S} / \mathrm{cm}$ & $4200-58,600$ \\
\hline Surface Tension & $\mathrm{dyn} / \mathrm{cm}$ & $43-78$ \\
\hline Density & $\mathrm{kg} / \mathrm{m}^{3}$ & $1014-1140$
\end{tabular}

PW salinity (salt concentration) can range from $1000 \mathrm{mg} / \mathrm{L}$ to more than $300,000 \mathrm{mg} / \mathrm{L}$, whereas seawater salinity ranges from $32,000 \mathrm{mg} / \mathrm{L}$ to $36,000 \mathrm{mg} / \mathrm{L}$. Chloride and sodium are the anion and cation with the greatest concentrations in PW, similar to those found in seawater. PW also contains soluble salt ions, such as calcium, magnesium, potassium, and bicarbonate. Sulfide is present in PW that originates from sulfur-bearing oil and gas sources and wells. Corrosion issues that stem from the high concentrations of salts, sulfurs, and sulfides should thus be considered, particularly for offshore PW treatment equipment. The inorganic composition of PW, including, significantly, heavy metals, is determined by the formation conditions and the chemicals injected into oil and gas reservoirs during exploration and production. Other elements, such as barium, iron, manganese, and zinc, are known elements that might be detected in PW which are not typically present in saltwater. These metal ions, which form undesired solids, may hinder the treatment processes [23,24]. The difference in quantities of these ions between PW and saltwater may be one of the primary causes of PW's high potential biological toxicity. Moreover, some anaerobic bacteria also exist in PW and can cause corrosion. The PW from oil fields and natural gas vary in terms of composition and concentration $[10,13,25]$.

\subsection{Concentrations of Radioactive Compounds in Produced Water}

In PW, both naturally and artificially occurring radionuclides are present because of anthropogenic activities. They are referred to as technologically enhanced, naturally occurring radioactive materials (TENORM). Their presence may be caused by uranium and thorium chains [23]. The water that is utilized in the production process may contain 
a specific amount of radioactive materials, such as $232 \mathrm{Th}, 238 \mathrm{U}, 226 \mathrm{Ra}, 228 \mathrm{Ra}, 210 \mathrm{~Pb}$, $224 \mathrm{Ra}$ [24]. Because of the presence of TENORMs, PW has radioactivity impacts on the environment and living organisms [26]. Leakages of TENORMs might have significant environmental impacts. Hence, it has received a lot of interest globally in recent years. The radioisotope values of PW in several regions of the world are presented in Table 2.

Table 2. Concentration of TENORMS in produced water from oilfields around the world.

\begin{tabular}{|c|c|c|c|}
\hline TENORMS & Concentration Bq. L-1 & Countries & References \\
\hline \multirow{5}{*}{$226 \mathrm{Ra}$} & $5.1-14.8$ & Algeria & [26-28] \\
\hline & $0.5-16$ & Norway & [22] \\
\hline & $13.8-111.2$ & Syria & [29] \\
\hline & $1.07-34.15,5-40$ & Egypt & {$[30,31]$} \\
\hline & $(<0.002-58)$ & USA & {$[32,33]$} \\
\hline \multirow[b]{2}{*}{$210 \mathrm{~Pb}$} & $<5$ & Poland & {$[34,35]$} \\
\hline & $2.6-16.7$ & USA & {$[32,33]$} \\
\hline \multirow{8}{*}{$228 \mathrm{Ra}$} & $<0.05-12.0$ & Brazil & {$[28,36]$} \\
\hline & $<0.02-13.26$ & Egypt & {$[32,33,37-39]$} \\
\hline & $<2$ & Poland & [34] \\
\hline & $<1-4$ & Turkey & [40] \\
\hline & $6.40-35.50$ & Ghana & {$[37,41]$} \\
\hline & 8.1 & Nigeria & {$[31,38]$} \\
\hline & $<1.1 \times 10^{-3}-9.6$ & Argentina & {$[42]$} \\
\hline & $35-763,0.02-59$ & USA & {$[32,33]$} \\
\hline \multirow{8}{*}{$40 \mathrm{~K}$} & 39.8 & Nigeria & {$[31,38]$} \\
\hline & $1.65-11.99$ & Ghana & {$[37,41]$} \\
\hline & $1522-1535$ & Oman & [43] \\
\hline & $221-899$ & Romania & [43] \\
\hline & $\begin{array}{c}4.4-43.7 \\
632.5-1448.7\end{array}$ & Egypt & {$[28,30]$} \\
\hline & $\begin{array}{c}032.3-1448.1 \\
14.6\end{array}$ & Iraq & {$[44,45]$} \\
\hline & $3.6-15.37$ & Azerbaijan & [29] \\
\hline & 7.3 & Iran & [46] \\
\hline \multirow{5}{*}{$238 \mathrm{U}$} & $<4.5 \times 10^{-3}$ & Congo & {$[41,42,46-48]$} \\
\hline & $7.3 \times 10^{-3}-1.5 \times 10^{-2}$ & Italy & [49] \\
\hline & $9.47-25.2$ & Egypt & {$[28,30]$} \\
\hline & 4.12 & Iraq & {$[44,45]$} \\
\hline & $0.043-1.1$ & Ghana & {$[37,41]$} \\
\hline
\end{tabular}

\subsection{The Impact of Produced Water on the Environment}

Environmental impacts caused by PW disposal since the mid-1800s have been reported after the first oil and gas wells were drilled and operated. The most commonly reported environmental concerns are soil degradation, and its effects on surface water, groundwater, and the ecosystem [50]. PW compounds are more hazardous and environmentally harmful than crude oil, and they may contaminate natural resources. Hazardous substances in high quantities are the most serious environmental issue when PW is discharged into the natural environment. Since produced water from offshore oil and gas production is mostly discharged into the ocean, it can impact the natural ecosystem and expose living organisms to harmful elements. PW is treated with gravity-based separation before being released into the environment. The discharge effects depend on a specific environment's physical, chemical, and biological composition because PW contains high levels of dissolved ions, hydrocarbons, and trace elements. The untreated PW discharge poses a significant threat to aquatic life and agricultural resources by altering the aquatic environment's natural state $[13,51]$. For agricultural purposes, high sodium and high conductivity in PW require further treatment to eliminate the risk of damaging crops and livestock. Large PW volumes cause environmental impacts, including the erosion of large land area disposal basins, 
pipelines, and road infrastructures. The size of the water body receiving the PW is critical in determining the environmental effects, as the ocean offers substantive dilution of discharge, while small streams have low dilution capacity.

The water body's physical properties are of primary concern, including its temperature, $\mathrm{pH}$, effervescence, and dissolved oxygen concentrations, which can be affected differently depending on the type of well that the PW originated from.

Non-polar oil in water (OIW) has been regulated by the government, whereas little attention has been given to the dissolved organic components in produced water [14,52]. Recent research has attempted to determine the long-term effects on the environment caused by the dissolved organic components, heavy metals, and production chemicals. Their effects are not fully documented or understood. Highly alkylated phenols, aromatic hydrocarbons, and a few metals are highly toxic to the environment, even at low concentrations, and cause bioaccumulation and toxicity [53]. The high concentration of salts in PW contributes to its toxic effects on soils, water quality, and ecosystems [54]. PW has higher salinity than seawater, and it destroys the quality of freshwater and degrades the quality of soil. High sodium levels can inhibit water filtration through the soil and may cause a deficiency of other essential ions required for growth $[55,56]$.

A previous study [57] reported that the amount of fatty acid that organic matter contains generates a high level of biological oxygen demand (BOD) and chemical oxygen demand (COD). In PW, most metal ions are in a dissolved form and are chemically reactive, but the metal concentration is slightly higher than seawater [58]. This can have an adverse effect on the receiving water body and aquatic life due to its bioaccumulation potential, and it may therefore harm biological communities [58,59]. Boron, lithium, bromine, fluorine, and radium are present in elevated concentrations, and these trace elements may even remain in soils after the saline water has been flushed away. Many trace elements are phytotoxic and are adsorbed in the soil. Schifter et al. [60] studied the effect of produced water effluents in Sonda de Campeche, located in the Gulf of Mexico. The study was based on the direct field sampling of effluent that had been released into the ocean in the years 2003-2013. The results showed that the sum of the average metal concentration increased from $272-1104 \mu \mathrm{g} / \mathrm{L}$ over 2003-2013.

A broad range of natural and artificial radioactivity is present in PW. Thus, their harmful effects on the environment vary from region to region, depending on how radionuclides enter the environment. This variance is represented in Figure 1. The bioaccumulation of $226 \mathrm{Ra}$ in the food series is a possible risk for living organisms; therefore, the ecosystem must be protected from this threat. The potassium isotope is a naturally occurring radioactive element, and it is being released in large quantities and mostly appears as a radionuclide in PW. Previous studies [37,61-64] reported that $34 \%$ of $40 \mathrm{k}$ isotope activity concentrations were found to be less than $20 \mathrm{~Bq} . \mathrm{L}^{-1}$ and approximately $25 \%$ ranged between 20 and $60 \mathrm{~Bq} \cdot \mathrm{L}^{-1}$. A high concentration of radioisotope in PW might lead to the contamination of agricultural soil and groundwater. The lead isotopes $214 \mathrm{~Pb}$ and $210 \mathrm{~Pb}$ are present in PW, and lead isotope activity concentrations are less than $20 \mathrm{~Bq} . \mathrm{L}^{-1}$ [65]. Lead isotopes, after release, degrade the soil and groundwater quality. The actinium (228 Ac) isotope poses a considerable long-term health risk due to its well-known toxicity at high levels [66]. The cesium $137 \mathrm{Cs}$ artificial radionuclide has also been detected in Iraqi oil PW because of the Gulf War and the Iraq War [44]. Previous studies [32,33,35,63] reported the presence of other radioisotopes at detectable levels, including $137 \mathrm{Ba}, 210 \mathrm{Po}$, $212 \mathrm{Bi}, 214 \mathrm{Bi}$, and $208 \mathrm{Ti}$, but with low activity concentrations in comparison to the aforementioned radioactive elements $[63,66]$. Recent research worldwide aims to highlight the need for ecosystem protection. Therefore, an appropriate preventative policy is required to address environmental issues, and protect against harmful organics, chemicals, and radioactive materials. 


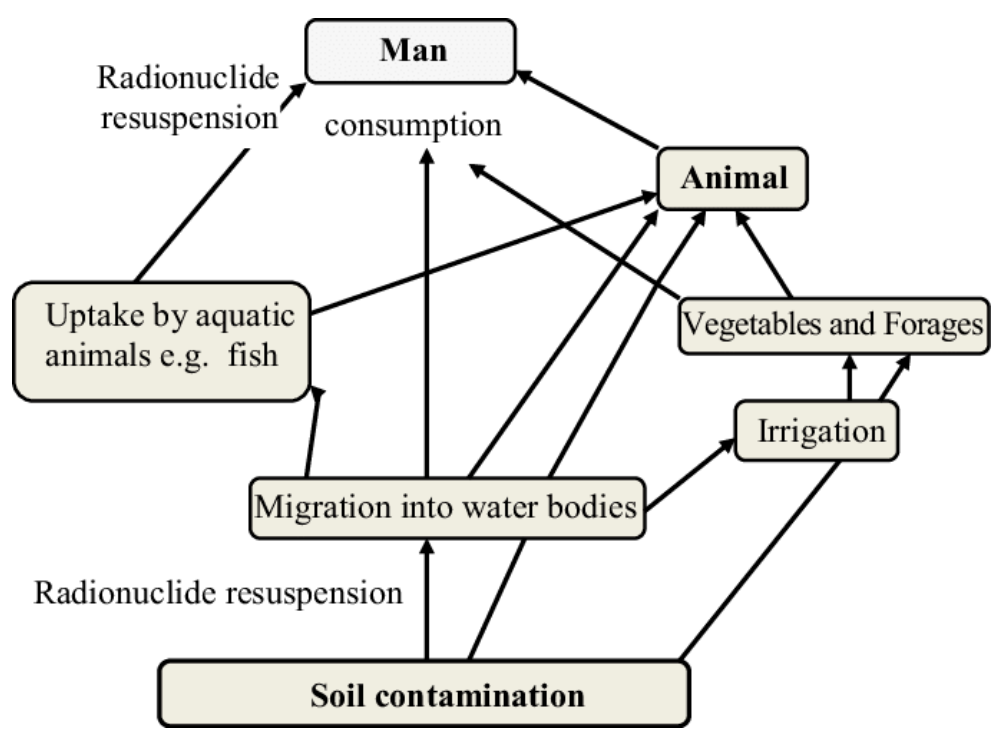

Figure 1. Radionuclide entry into the environment [67].

\subsection{The Impact of Produced Water on Human Health}

The increase in produced water volumes across the world and its ongoing consequences impact the lives of present and future generations. The use of contaminated water has several negative impacts on human health. Significantly, it causes typhoid, cholera, hepatitis, and various other disorders. Despite the toxic composition of PW and its effects on human health, minimal focus has been given to the issue, and limited studies have been conducted. Contamination by heavy metals has proven to be a severe problem with several health hazards. According to the Agency for Toxic Substances and Disease Registry, metals and metalloids, such as $\mathrm{As}, \mathrm{Cr}, \mathrm{Cd}, \mathrm{Ni}, \mathrm{Cu}, \mathrm{Zn}$, and $\mathrm{Pb}$, are ranked on the 275 extremely toxic pollutants list. Overall, the harmful effects of toxic heavy metals are summarized in Figure 2.

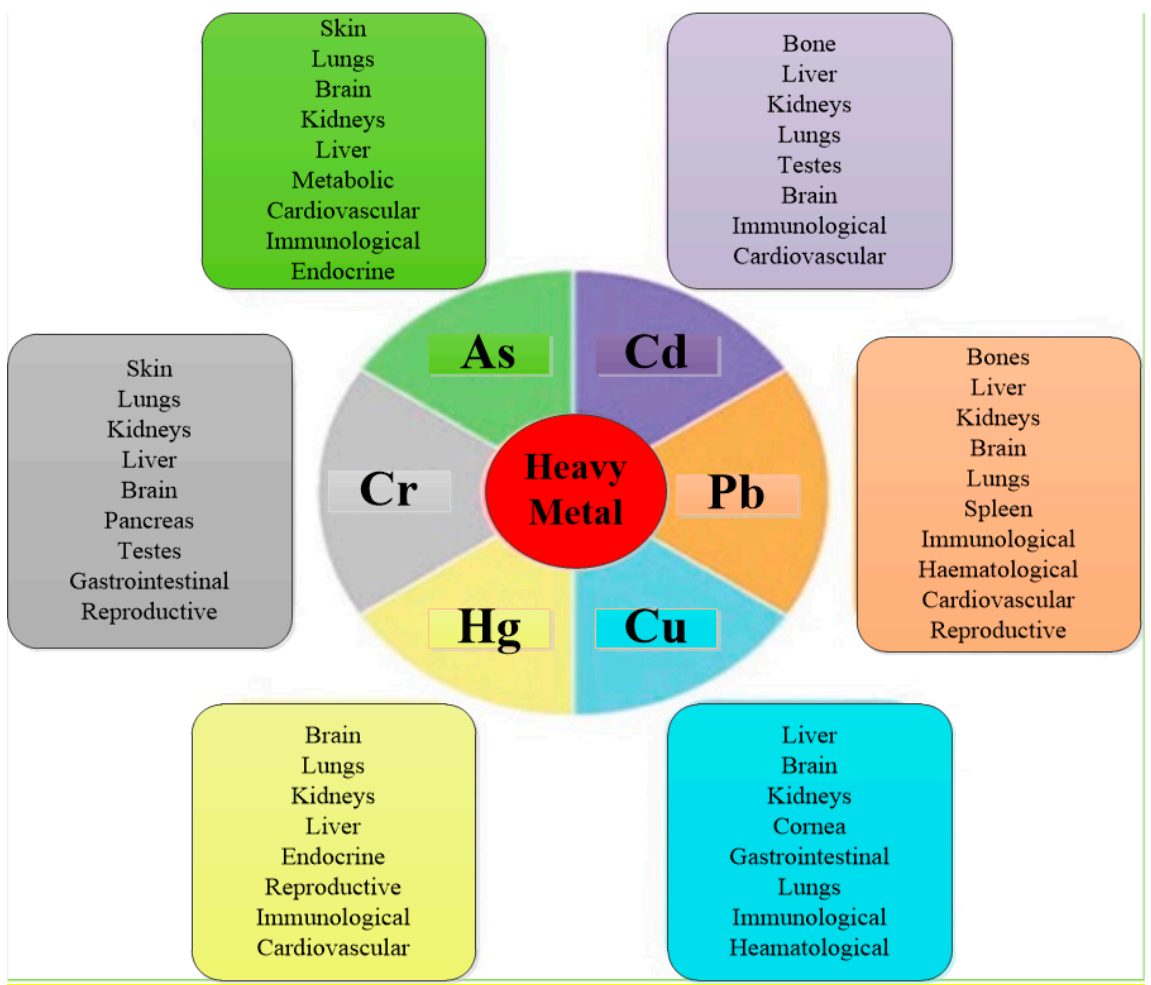

Figure 2. Harmful effects of heavy metals on human health. Figure was reproduced from [68]. 
Previous studies $[52,69,70]$ have reported that metals and hydrocarbons from oil fields are toxic, showing how exposure to alkylphenols has negative impacts on both the organs and fertility of fishes. Toxicity in produced water can be either acute or chronic. The LC 50 test is used to measure acute toxicity, whereas the long-term effects are more difficult to quantify [13,59]. Holdway et al. [71] argued that long-term chronic exposure could cause growth and developmental problems, fecundity, genetic diversity, and lower reproductive success. It may also cause respiratory issues, physiological disorders, and endocrine disruption. Despite this, radium-bearing scales and sludge found in oilfield equipment are being discarded on soils, which poses additional hazards to human health.

The presence of a wide range of radioactivity in PW makes it critical to consider the effects on public health. Radionuclide emissions and their long-term persistence in the environment might cause long-term external irradiation or internal contamination via food or water consumption for populations living in affected regions. Radionuclides and their compounds are harmful in two ways. Chemical toxicity is induced because of the chemical characteristics of the elements and molecules that make up the material. Radiotoxicity refers to the toxicity of radioactive elements and nuclides. Inhalation and ingestion of a small number of radium isotopes (226 Ra, $228 \mathrm{Ra}$, and $224 \mathrm{Ra}$ ) may lead to their accumulation which can cause serious harm over the long term. Continuous exposure to radium results in bone and sinus cancer.

Moreover, they can potentially cause common diseases, such as nasal mucosa and bone tumors [72]. One investigation [49] reported that PW's uranium and thorium isotope activity concentrations are less than $20 \mathrm{~Bq} . \mathrm{L}^{-1}$. Water polluted with depleted uranium or thorium will undoubtedly cause many diseases to the consumer due to its penetration into the soil and water [73].

\subsection{Produced Water Management-Discharge}

Nowadays, managing PW requires considering all the factors while making decisions regarding management alternatives. Oil and gas companies face significant technical and economic challenges in the disposal and management of PW. The fundamental differences between offshore and onshore PW management are weight and space constraints, which impacts total treatment efficiency. Different management systems are also influenced by differences in environmental regulations and standards, as well as differences in the production volume and targeted pollutants. While onshore operations focus on reducing salt content, oil and grease levels are the primary concern in offshore operations [3]. Stream management is necessary to manage the production of hydrocarbon waste. The cost of managing PW varies according to the operational techniques. A technique for PW management that is both economical and eco-friendly would be considered to be the best practice in all industries.

The United States produces approximately 890 billion gallons of PW annually [74] from seven key oil and gas basins [75]. With the unconventional nature of oil and gas development, the PW volume generated each year keeps increasing, with levels reaching more than $50 \%$ of the amount of crude oil and natural gas [76]. Reinjection of more than $55 \%$ of the PW into wells is common nowadays, but this means that the PW rests on open surfaces [77,78]. The global estimated treatment cost of PW is USD 40 billion per annum, and the disposal cost depends on the method, but typically ranges between 0.3-10 USD/bbl [79]. PW treatment with conventional techniques, such as hydro cyclone, media filters, and gravity separation, could generate treated water for reinjection at the cost of $0.509 \mathrm{USD} / \mathrm{m}^{3}$ of water. For PW recycling, the improved technique will produce recyclable water at the cost of $3.808 \mathrm{USD} / \mathrm{m}^{3}$ of water [80]. Figure 3 shows that the average costs percentage in the USA for handling water production [78]. 


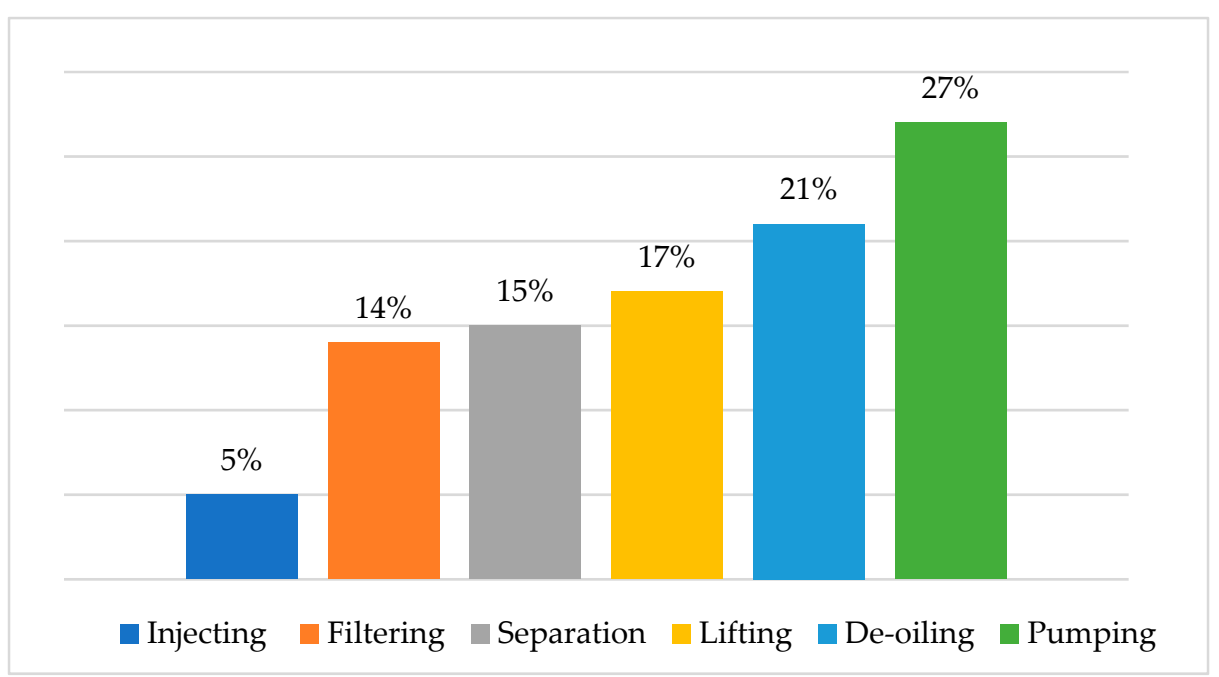

Figure 3. The produced water treatment and disposal life cycle cost in the USA (data obtained from [78]).

To regulate effluent discharge, countries have different environmental and federal regulations and limits for the content in PW [81], as presented in Table 3. For offshore PW, only oil and grease content is regulated because the ocean has a high salt concentration, so salinity is not a concern. For onshore PW, both oil and salt parameters are regulated. For reinjection, then, oil content, solids, and bacteria must be eliminated. The limits on the amount of oil permitted in water vary from country to country. Different nations have set strict environmental rules and requirements for the discharge of produced water. The daily maximum limit for oil and grease is $42 \mathrm{mg} / \mathrm{L}$, and the average monthly limit is $29 \mathrm{mg} / \mathrm{L}$, according to the EPA's effluent regulations for oil and gas extraction [82] (Table 3). After complying with environmental rules and standards using treatment equipment, PW from offshore oil and gas operations is often discharged directly into the ocean. At the same time, onshore operations manage the vast majority of PW by injecting it back into the wells. What little else remains is released, reused, or evaporated [83].

Table 3. Produced water effluents discharge limit for different countries $[84,85]$.

\begin{tabular}{cccc}
\hline \multirow{2}{*}{ Country } & \multicolumn{2}{c}{ Effluent Limits } & \multirow{2}{*}{ Reporting Routine } \\
\cline { 2 - 3 } & Monthly & Daily & \\
\hline Canada & $40 \mathrm{ppm}$ monthly avg. & $80 \mathrm{ppm}$ 2-day avg & Annual \\
USA & $29 \mathrm{mg} / \mathrm{L}$ monthly avg. & $42 \mathrm{mg} / \mathrm{L}$ daily max & Monthly \\
UK & $40 \mathrm{ppm}$ monthly avg. & - & Annual \\
Western Australia & $30 \mathrm{ppm}$ monthly avg. & $50 \mathrm{mg} / \mathrm{L}$ daily max & - \\
Mediterranean Sea & $40 \mathrm{ppm}$ monthly avg. & - & - \\
\hline
\end{tabular}

\subsection{The Reuse of Produced Water}

Another potential alternative in water management is the reuse of produced water, aiming to minimize demand for water. Produced water is a reusable resource that can be utilized for various purposes, i.e., drinking water, irrigation, industrial uses, and livestock watering. The EPA has provided standards that are more stringent for drinking water and, therefore, more extensive PW treatment is needed [86]. Additionally, to reuse treated water for irrigation and livestock, standards have been laid out by the US Department of Agriculture Natural Resources Conservation Service [87]. It may be used in the industry for various purposes, including platform cleaning and ship balancing. PW might therefore meet the water requirements of many industrial operations in water-stressed areas. 


\section{Produced Water Treatment}

Several technologies for PW treatment have been proposed that focus on different contaminants. Previously, various methods have been reported for produced water treatment $[7,88-90]$, such as physicochemical and biological methods. A series of individual unit processes are required for contaminant removal instead of a signal process, which might not remove all pollutants. Treated PW could be reused for industrial and agricultural purposes. PW contains varying concentrations of different contaminants (oil and grease, dissolved gases, radioactive materials, metals, organics, solids, salts, and microorganisms), and it is challenging to select a suitable treatment method [91]. Treatment costs largely depend on the quality of the influent, energy costs, and plant capacity. The quality of the effluent and the cheapness of the method must be taken into account when considering appropriate PW treatment [92]. Due to the space constraint and equipment weight capacity, offshore PW treatment is challenging. PW treatment requires different treatment steps to remove contaminants. PW volume increases day by day, and other techniques have been reported in the literature for its treatment, such as membrane filtration, adsorption, and chemical precipitation. Determinations on the most cost-effective treatment and the desired water quality standards for reuse or discharge can change the selection of appropriate techniques. The freshwater shortage is increasing globally; PW could therefore be a vital water source after appropriate PW treatment. In the next subsections, adsorption is discussed in detail.

\subsection{Adsorption Classification}

Adsorption is considered to be an old, cheap, and much-improved technique that can help improve quality water [93]. Adsorption is an exothermic process, and its mechanism involves the attachment of either gas or solid substances onto an adsorbent surface, as shown in Figure 4.

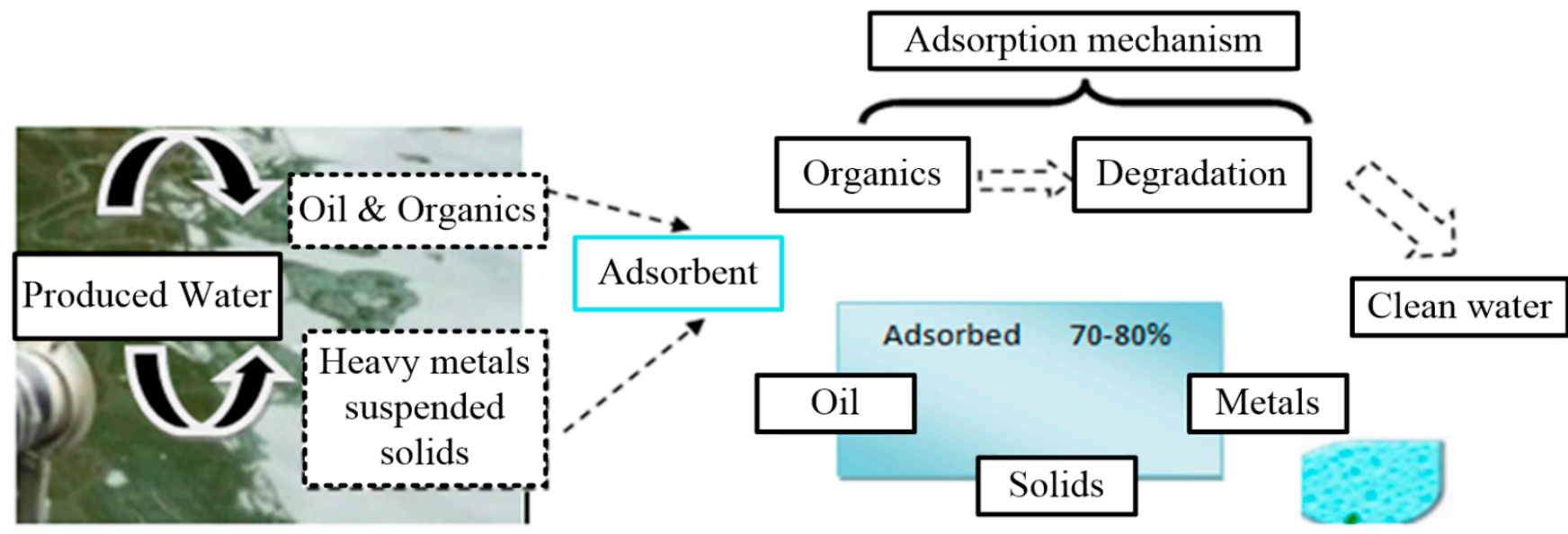

Figure 4. Adsorption mechanism for produced water contaminants.

Adsorption is typically divided into two categories: physisorption and chemisorption. This categorization is determined by the strength of the interaction between the substrate and the adsorbate. During isotherm and kinetic studies, this interaction has been identified. For example, if the kinetic model is fitted to a pseudo-second-order model, it posits that one adsorbate ion can occupy two surface sites; this suggests that the adsorption is classified as chemisorption [94]. Chemisorption occurs when electrons are exchanged or shared between the sorbate and the sorbent to form a covalent or ionic link. To put it another way, chemisorption is based on chemical interactions between the adsorbate and the adsorbent's surface sites. Because of the strong chemical interaction between adsorbate and adsorbent, it is more difficult to reverse, and removing the adsorbed molecules requires more energy than physical adsorption [95]. Chemisorption increases with temperature at first, then 
reaches its maximum strength. Chemisorption is more common in heavy metal removal than other methods because it has stronger interactions and a larger adsorption capability for heavy metals.

Physisorption is a broad word that includes all weak electrostatic interactions, such as van der walls, hydrogen bonding, and dipole-dipole interactions between the sorbent and sorbate, with interactions generally ranging from 0.2 to $4 \mathrm{~kJ} / \mathrm{mol}[95,96]$. These are the weakest of the interactions and are quickly broken. When the temperature is low, physisorption occurs, and as the temperature rises, it decreases [97]. Other reported interactions include ion exchange, and precipitation. With a specified adsorbent, more than one interaction can occur during the adsorption process, but the rate and type of interactions vary due to material composition, contaminants' structure and properties, and the solution conditions.

Adsorption techniques have some attractive characteristics, including process simplicity, cost effectiveness, resistance to toxic substances, and flexibility in the scaling-up process. The cost of the process depends upon the adsorbent material. The literature has reported $[55,98,99]$ that adsorption is effective at removing organics, BTEX, oil, TOC, and more than $80 \%$ of heavy metals from PW, and the overall adsorption mechanism is shown in Figure 4. The activated carbon and organoclay combination has proven to be more efficient at removing total petroleum hydrocarbons (TPH) [100]. Oil content has been reduced by up to 85\% in PW through the use of copolymers [101]. Zeolites have proved to be as efficient at removing BTEX compounds as the other methods [102]. Due to space constraints, efficient physical and chemical treatment technologies are preferred [13,103].

\subsection{Factors Affecting the Adsorption Performance}

The operational parameters, such as the $\mathrm{pH}$ of the solution, the temperature, the contact time, the mass of the adsorbent, and the surface area impact the interaction between adsorbate and adsorbent.

The $\mathrm{pH}$ level is most susceptible to change in adsorption investigations since $\mathrm{H}^{+}$ powerful absorbent. The ionization of surface functional groups and the selection of metal ions are both affected by the $\mathrm{pH}$. It is considered to be one of the most critical factors affecting the binding sites, the chemical nature of the adsorbent's surface, and the hydrogen ions. Furthermore, $\mathrm{pH}$ is considered to play an essential role in the adsorption system, especially in aqueous solutions, because it affects the character of each ion being removed and the adsorbents (where adsorption phenomena disappear and change to precipitation when the $\mathrm{pH}$ exceeds 7) [104]. Moreover, an increase in the $\mathrm{pH}$ enhances the pollutant removal efficiency. The removal rate of pollutants decreases at optimum pH levels. Imamoglu et al. [105] studied lead (II) and Cu (II) removal by activated carbon at different $\mathrm{pH}$ values, and the results revealed that many factors could be controlled by $\mathrm{pH}$, such as the degree of ionization, the charge of the adsorbent material, and the specifications of the adsorbate. Krishnan et al. [106] found that the adsorbent's pH decreased when the acidic group on the adsorbent surface increased in size. The palm tree branches were activated by acidic groups that raised the positive charge on the adsorbent surface. The adsorbent was activated by $20 \%$ and $50 \% \mathrm{H}_{3} \mathrm{PO}_{4}$. The adsorptive capability of the adsorbent can be enhanced by changing the $\mathrm{pH}$. If the $\mathrm{pH}$ of a solution is greater than the adsorbent $\mathrm{pH}$, it provides the negative surface charge information by adsorbing cationic species. If $\mathrm{pH}<\mathrm{pH}_{\mathrm{pzc}}$ (point of zero charge $\mathrm{PZC}$ ), it will adsorb anionic species during adsorption. Therefore, the $\mathrm{pH}$ of a solution has a significant effect on the adsorbent's adsorption capacity [107].

Temperature contributes to the adsorption process. At high temperatures, the adsorption rate increases as the solution's viscosity decreases. Adsorbate mobility also rises at a higher temperature. In physical adsorption, the removal efficiency of pollutants decreases with an increase in temperature, whereas in chemical adsorption, with an increase in temperature, adsorption increased initially and then started decreasing. Renugadevi et al. [108] 
studied the effects of activated carbon on methylene blue, and found that adsorption depends significantly on the temperature [109].

Contact time can be defined as the time required to achieve equilibrium. Therefore, when equilibrium is reached determines the proper contact time. Moreover, a longer contact time allows for more efficient adsorption [108].

The adsorption efficiency depends substantially on the smaller particle size and high surface area of the adsorbent. The surface area increases with the decrease in the size of the particle. An ideal adsorbent should be mechanically stable, have high active surface sites and hydrophobicity, and be eco-friendly and economically feasible [110]. Final solute concentration and the adsorption performances significantly depend on the adsorbent's particle size. Smaller contaminant particles can adsorb more readily onto the adsorbent than larger contaminant particles [111]. Therefore, the large particles have a small surface area, causing a comparative reduction in the final uptake of the contaminants. New active sites are formed due to the increased adsorbent surface area, resulting in more solute molecules binding. Larger particles have a lower surface area, affecting the final uptake of the contaminants. New active sites are formed by increasing the adsorbent's surface area to allow the binding of solute molecules. Matsui et al. [112] investigated the particle sizes of different zeolites and reported that the uptake of particles was $10 \%$ higher for the size of 75-100 $\mu \mathrm{m}$ than those of 150-250 $\mu \mathrm{m}$.

Adsorbent dose plays a crucial role in increasing the adsorption rate [113]. The capacity of a solid adsorbent for a given concentration of adsorbate in a solution is usually determined by the influence of the adsorbent mass. Elsayed and Osman [104] and Mahmudi and Arsad [114] speculate that the availability of exchange sites on the surface area influences the effect of adsorbent dosage on adsorption capacity. The maximum removal of adsorbate ions from the solution was achieved before the saturation point; subsequently, no further change was observed in the amount removed. The usage of more adsorbents will therefore not affect the process of removal.

\subsection{Conventional and Non-Conventional Adsorbents for Produced Water Treatment}

Copolymers, resins, organoclay, activated carbon, and zeolite are broadly used for water treatment. Activated carbon has an extended surface area, high surface reactivity, a microporous structure, and high adsorption ability. Functional groups are responsible for its catalytic and physicochemical characteristics. It is the most widely used adsorbent for treating wastewater; however, its use is limited because of its high cost [113]. To overcome this problem, different environmentally friendly, cost-effective, and non-conventional adsorbents have been developed for PW treatment that are made from other waste, such as fruits and plants, wood, fossil fuels, and agricultural waste [115], as shown in Figure 5.

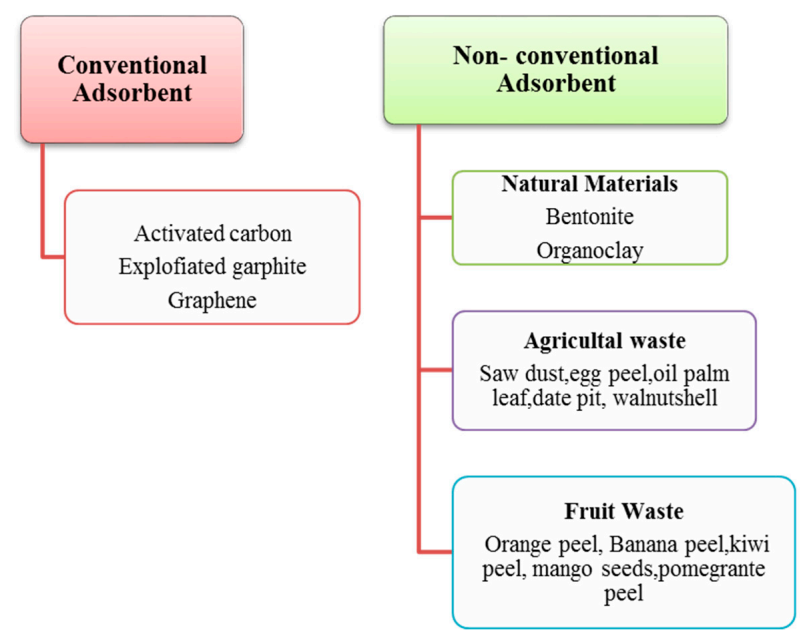

Figure 5. Different conventional and non-conventional adsorbents for PW treatment. 


\subsection{Produced Water Treatment}

\subsubsection{Oil Removal}

The concentration of oil and grease (O\&G) in PW ranges between 6 and $60 \mathrm{mg} / \mathrm{L}$ [116]. Johnson et al. [117] and the United States Environmental Protection Agency reported that oil and grease concentrations in PW range between 2.3 and $60 \mathrm{mg} / \mathrm{L}$ and 2.3 and $38.8 \mathrm{mg} / \mathrm{L}$, respectively. Another study was conducted on PW in the western United States, and the concentration of O\&G was found to be from $40 \mathrm{mg} / \mathrm{L}$ to as high as $2000 \mathrm{mg} / \mathrm{L}$ [23]. Different adsorbents have been used in PW for oil removal, as shown in Figure 6. Ibrahim et al. [118] used pomegranate peel powder (PPP) as an adsorbent. The results showed that the oil removal efficiency could be increased using the optimum adsorbent dosage, adsorbent concentration, and $\mathrm{pH}$ value. It is a low-cost adsorbent, and a $92 \%$ removal efficiency rate has been reported with a reaction time of $50 \mathrm{~min}$. Another study used kiwi peel as an active and low-cost adsorbent [119]. The oil adsorption was strongly dependent on contact time, adsorbent dose, and the $\mathrm{pH}$ of the kiwi peels. Results revealed that an almost $90 \%$ removal efficiency rate could be achieved at a $\mathrm{pH}$ of 2.16 and with a contact time of $150 \mathrm{~min}$ for $1.5 \mathrm{~g}$ kiwi peels. Alsulaili and Fahim [120] used walnut shells and date pits as an adsorbent for oil removal. The results showed that oil adsorption capacities for date pits and walnut shells were $80 \%$ and $87 \%$, respectively.

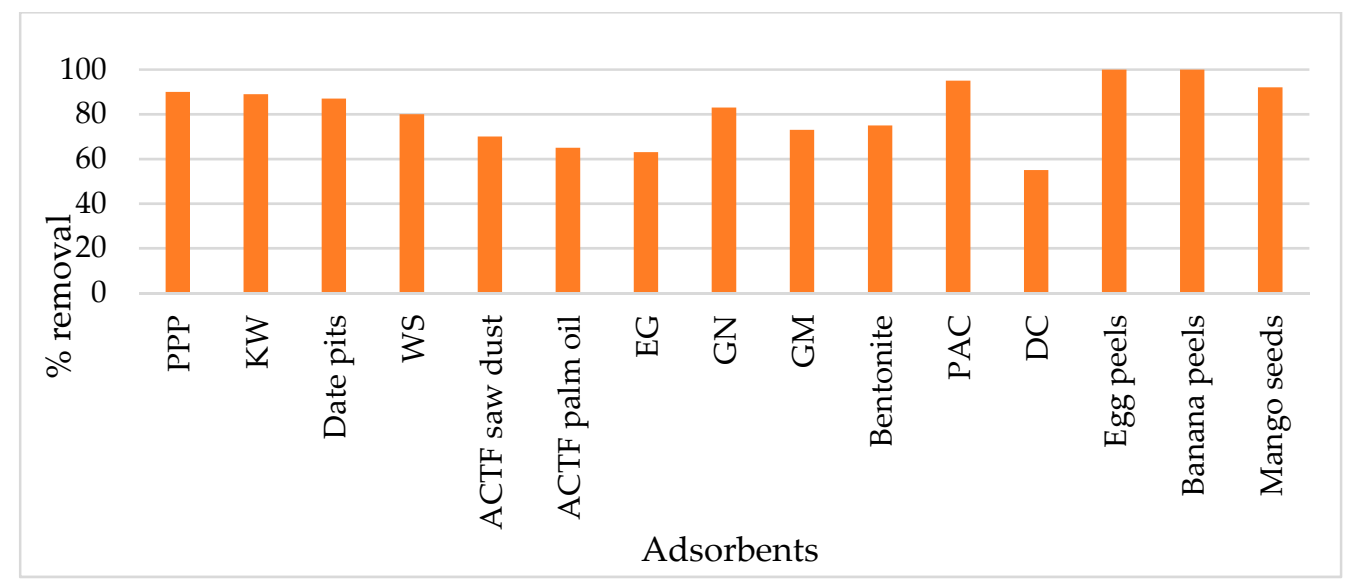

Figure 6. Removal of oil from produced water for the various adsorbents, including PPP (pomegranate peel powder), EG (exfoliated graphite), KW (kiwi), WS (walnut shell), GN (graphene nanoplatelets), GM (graphene magnetite), PAC (powdered activated carbon), and DC (deposit carbon).

El-Syed et al. [121] investigated the use of synthesized amorphous carbon thin films that were derived from sawdust wood and utilized them for oil adsorption in a fixed-bed column system. A maximum uptake of $700 \mathrm{mg}$ oil/g adsorbent was obtained at a flow rate of $0.5 \mathrm{~mL} \mathrm{~min}^{-1}$ and with a bed height of $5 \mathrm{~mm}$. Takeuchi et al. [122] studied the use of exfoliated graphite (EG), and the result showed that 278 and $66 \mathrm{mg} / \mathrm{L}$ of oil was decreased to $1.2 \mathrm{mg} / \mathrm{L}$ and undetectable, respectively. Abou et al. [123] investigated the use of graphene magnetite and PAC for oil removal, and the results showed that the increased contact time and dosage of the adsorbent increased oil removal. The removal efficiency depends on the optimum parameters that play an essential role in adsorption. Okiel and El-Sayed [124] used powdered activated carbon, deposited carbon (DC), and bentonite, which illustrated the importance of contact time in the adsorption technique. Muhammad et al. [125] investigated the use of eggshells and achieved a 100\% removal efficiency rate with a $1.8 \mathrm{~g} / \mathrm{L}$ adsorbent dose.

El-Nafaty and Muhammad [126] used $267 \mathrm{mg} / \mathrm{L}$ of banana peels with $35 \mathrm{~min}$ of contact time and achieved a 100\% oil removal efficiency rate. Another study was carried out using mango seeds that achieved a 93.3\% removal efficiency rate [127]. Alther [128,129] investigated the use of organoclay, and results showed that removal efficiency is seven times higher than activated carbon and at a lower cost. It can be used as an alternative 
adsorbent instead of granular activated carbon. Adsorption technology with low-cost adsorbents has been shown to be good at treating oily PW to a certain extent. Oily produced water treatment is a huge problem for the oil and gas industry because it has mostly been reinjected back into the wells to increase oil production and disposal. Low-cost adsorbents, prepared from various cheap organic waste materials, can minimize waste disposal in the environment, and can also be used for pretreatment.

\subsubsection{Total Organic Carbon (TOC) Removal}

Total organic carbon levels in PW range from 0 to 1500 (mg/L) [92,130]. Naturally occurring water has a TOC concentration between less than $0.1 \mathrm{mg} / \mathrm{L}$ and greater than $11,000 \mathrm{mg} / \mathrm{L}$ [131]. Ayers and Parker [132] found a TOC value of $300 \mathrm{mg} / \mathrm{L}$ in PW from Hibernia platforms, while TOC levels were in the range of $67-620 \mathrm{mg} / \mathrm{L}$ in PW from Louisiana rigs [133]. Gallo et al. [134] studied the adsorption properties of organic compounds, including cocoa beans, bananas, orange peel, palm shells, sawdust, and passion fruit peel, comparing them to the walnut shells that are currently the main commercially used adsorbent in PW. Before adsorption, all adsorbents undergo pretreatment, and only sawdust palm and walnut shell can be used as an adsorbent for PW. The study found that the maximum removal efficiency rate achieved using sawdust, palm shell, and walnut shell was $33,5.6,4.9 \mathrm{mg} / \mathrm{g}$ of the dry adsorbent, respectively. Breakthrough curves indicate that palm shell saturates much faster than walnut shell. Takeuchi et al. [122] used exfoliated graphite to remove TOC from PW and found that TOC concentrations decreased from $566 \mathrm{mg} / \mathrm{L}$ to $1.5 \mathrm{mg} / \mathrm{L}$ in the effluent.

\subsubsection{BTEX Removal}

BTEX are volatile aromatic compounds naturally present in oil and gas products, and they can easily escape into the atmosphere during the water treatment process. Different studies have been conducted to determine the concentrations of BTEX in PW. The highest concentration was of benzene, which ranged between 0.44 and $2.80 \mathrm{mg} / \mathrm{L}$ and was reported in the PW of the Gulf of Mexico, followed by toluene, xylene, and ethylbenzene. Dorea et al. [135] investigated BTEX concentrations in Permian basin PW and found that the highest concentration was of benzene, with $1.5-778.51 \mathrm{mg} / \mathrm{L}$, followed by ethylbenzene, xylenes, and toluene. Different adsorbents have been used for BTEX removal from PW, as shown in Table 4. In one study, organic clay was modified with a surfactant, but it was not efficient enough to remove BTEX [136]. It has a microstructure, high effectiveness, and a low cost. The outcome showed that $95.6 \%$ of the contaminant removal was achieved within $3 \mathrm{~h}$, with the most-removed contaminant being ethylbenzene, followed by xylene, toluene, and benzene. Costa et al. [137] investigated the effectiveness of peat and sawdust for removing BTEX. It has been reported that peat and sawdust attained the highest efficiencies of $67 \%$ and $57 \%$ in removing xylene. A few studies used modified clay extensively for BTEX removal. Carvalho et al. [138] studied smectite clay and transformed it into an organophilic adsorbent using $\mathrm{Na}_{2} \mathrm{CO}_{3}$ and a hexadecyl trimethyl ammonium chloride (HDTMA) treatment. Removal rates of almost $55 \%$ and $90 \%$ were achieved. Egbuchunam et al. [139] investigated the use of surfactant-modified kaolinite (SMK) for BTEX removal from aqueous media. Kaolinite clay is an effective adsorbent due to its highly adsorptive surface area and ion-exchange properties. Sharmasarka et al. [140] investigated the use of trimethylphenylammonium (SWy-TMPA), trimethylammonium adamantane (SWy-Adam), and HDTMA montmorillonite-derivatives for BTEX removal. The results showed that the BTEX mixture's total adsorbed amounts were higher with HDTMA than with the individual compounds.

\subsubsection{Metals Removal}

PW contains certain metals, such as arsenic, cadmium, chromium, lead, and nickel. However, the concentration and chemical content differences are influenced by the geological age, injected water volume, and chemical composition [141]. The concentration of 
heavy metals in PW is often higher than in seawater. According to the Agency for Toxic Substances and Disease Registry, metals and metalloids, such as As, $\mathrm{Cr}, \mathrm{Cd}, \mathrm{Ni}, \mathrm{Cu}, \mathrm{Zn}$, and $\mathrm{Pb}$, are ranked as extremely toxic pollutants [142]. According to Spellman et al. [143], the removal of $85 \%$ of heavy metals could be obtained through the adsorption process. Kose et al. [144] used activated carbon for water treatment as a pretreatment technique. The results showed that metal removal from PW by the granular activated carbon microfiltration the best result using reverse osmosis. Houcine and Mejri [145] used lime in the produced water of southern Tunisia to treat heavy metals, including lead, zinc, iron, manganese, and barium. Lime proved to be an efficient and economical filtration process for heavy metal elimination, and a 95\% removal efficiency rate could be achieved. According to Mahmoud et al. [118], with reed bed technology, a 78\% removal efficiency rate was achieved for $\mathrm{Al}, \mathrm{Ba}, \mathrm{Cr}, \mathrm{Cu}, \mathrm{Zn}$, though the rate was $40 \%$ for $\mathrm{Fe}, \mathrm{Li}, \mathrm{Mn}, \mathrm{Pb}, \mathrm{Cd}$, and Ni. Another study was conducted by Fardet al. [146] for barium removal using an MXene nano adsorbent, and a 90\% removal efficiency rate was attained, in which the $\mathrm{pH}$ was the most dominant factor. Table 4, illustrated the removal of produced water contaminates using different adsorbents.

Table 4. Different types of adsorbent used for produced water treatment.

\begin{tabular}{|c|c|c|c|c|}
\hline Adsorbent & Targeted Pollutant & \% Removal & Limitations & References \\
\hline Sawdust & COD & $33 \%$ & $\begin{array}{l}\text { Pre-treatment required to } \\
\text { enhance efficiency }\end{array}$ & [134] \\
\hline Walnut shell & COD & $49 \%$ & Carbon is lost during reactivation & [134] \\
\hline Palm shell & COD & $56 \%$ & Loss of carbon during activation & [134] \\
\hline Lime & $\begin{array}{l}\text { Heavy } \\
\text { metals }\end{array}$ & $95 \%$ & $\begin{array}{l}\text { pH dependent; produces a large } \\
\text { amount of sludge; overdose can } \\
\text { cause poor effluent quality }\end{array}$ & [145] \\
\hline Mxene nano adsorbent & Barium & $90 \%$ & Structure is not stable & [146] \\
\hline Exfoliated graphite & TOC & - & $\begin{array}{l}\text { Poor hydrophobicity; difficult to } \\
\text { handle on-site because of their } \\
\text { granular or powder forms }\end{array}$ & [122] \\
\hline $\begin{array}{l}\text { Peat and } \\
\text { sawdust }\end{array}$ & BTEX & $67.8 \%$ and $57.8 \%$ & $\begin{array}{l}\text { Mechanical strength of peat is low, } \\
\text { and pretreatments are required to } \\
\text { enhance the efficiency of sawdust }\end{array}$ & [137] \\
\hline $\begin{array}{l}\text { Modified } \\
\text { organoclay }\end{array}$ & BTEX & $95.6 \%$ & $\begin{array}{l}\text { Not suitable for pollutants that have } \\
\text { a strongly acidic character; poor } \\
\text { reusability and oil recovery }\end{array}$ & [138] \\
\hline
\end{tabular}

\subsection{Adsorption Limitations}

Activated carbon has a 70 to $85 \%$ removal efficiency rate. However, suspended contaminant particles have a low capacity and weak interaction, and there are difficulties in the regeneration of the material used as an adsorbent, while the adsorbate can decrease the removal efficiency. Moreover, the shortcomings include high installation, maintenance, and regeneration cost [147]. Another disadvantage of the adsorption process is the waste disposal requirements. After a few batch treatments, regeneration of the activated carbon is needed. Otherwise, the removal efficiency decreases significantly. Adsorbent regeneration requires various chemicals, such as organic solvents, acids, bases, and redox agents. Reactivation depends on a few factors, such as the water usage rate, contaminant concentrations, and contaminant type. The adsorbent's surface can be modified with a hydrophilic group to enhance the surface area and porosity so as to target specific toxic materials. Several pretreatment techniques for PW adsorption treatments need to be considered in order to determine the most appropriate technique. Continuous process methods are principally eschewed at the industrial scale since they are expensive, require equipment and con- 
stant adsorbate concentrations, longer residence times, and better mass and heat transfer behavior. Overall, adsorption advantages and disadvantages are summarized in Table 5.

Table 5. Advantages and disadvantages of adsorption.

\begin{tabular}{cr}
\hline Advantages & Disadvantages \\
\hline It is feasible for all the contaminants present in PW & It cannot remove TDS and salt concentrations \\
\hline It can considerably reduce TOC, BTEX, and oil concentrations & For media regeneration, expensive chemicals are required \\
\hline It is used as a polishing step in PW to achieve the best results & $\begin{array}{c}\text { It cannot be used as a major treatment process due to the rapid } \\
\text { consumption of adsorbent material }\end{array}$ \\
\hline $\begin{array}{c}\text { It uses compact, packed bed modules, and is cheaper, efficient, } \\
\text { and requires minimal energy }\end{array}$ & $\begin{array}{c}\text { A disposal system is required for waste generated by used } \\
\text { adsorbent media, or some form of regeneration }\end{array}$ \\
\hline It can remove 80\% of heavy metals & It has a high retention time
\end{tabular}

\subsection{Adsorption Isotherms and Kinetics}

Adsorption isotherms explain the interactions taking place between the adsorbent and adsorbate at the equilibrium stage. The interaction is based on the adsorbent, adsorbate, and solution characteristics. Contaminant removal from wastewater has become one of the major research focuses nowadays [148]. Various empirical models have been introduced to interpret the experimental data and understand the adsorption equilibrium of PW contaminants on different adsorbents, but Langmuir's and Freundlich's models are the most widely utilized. In the Langmuir model, adsorption is considered to be driven by a monolayer on homogeneous surfaces without interaction among the adsorbed molecules. The Freundlich model explains that multilayer adsorption occurs on a surface that has a heterogeneous distribution of active sites in the form of a monolayer.

Alsulaili and Fahim [120] studied the oil and organic pollutant adsorption properties of date pits and walnut shells. The isotherms data for the date pit fitted well to the Langmuir model, and the data for the walnut shell to the Freundlich model. Pathak et al. [113] used the Langmuir and Freundlich equations to fit the adsorption data of $\mathrm{Cd}$ (II), Ni, Cr, and $\mathrm{Pb}(\mathrm{II})$. The $\mathrm{R}^{2}$ indicated that the Langmuir equation fits better than Freundlich's. It also suggested that adsorption on the FPW is most often monolayered. The cured oil adsorption by PPP, with an adsorption capacity of $555 \mathrm{mg} / \mathrm{g}$, was fitted using the Langmuir isotherms [118]. Gallo et al. [134] tested three adsorption models, and found that the Langmuir model best describes the experimental data on the contaminants adsorption. The Langmuir model mostly fits the adsorption data for oil [126]. The adsorption of cured oil on powdered activated carbon, bentonite, and deposited carbon in equilibrium studies followed a Freundlich isotherm model, indicating multilayer adsorption. Increased oil adsorption was observed when the initial adsorbent dose and contact time were increased [124]. The adsorption of crude oil onto eggplant peel best fitted the Langmuir isotherm model. It can be concluded that the Langmuir model is more suitable for describing the equilibrium adsorption of heavy metals and oil in most cases. However, some studies showed that the oil adsorption dynamic data fit the Freundlich isotherm model better than Langmuir's, as shown in Table 6.

Adsorption kinetics studies provide essential information about the rate of adsorption. The adsorption process may involve different transport stages. Adsorption kinetics explain the rate of adsorbate uptake, which physically controls the diffusion process and the residence time of adsorbate uptake at the solid-solution interface. The methods involve bulk diffusion, external mass transfer, intraparticle diffusion, and chemisorption. Three kinds of kinetic models are generally used, including the pseudo-first-order, pseudosecond-order, and Elovich models. The best-fit kinetic models for analyzing the removal of contaminants with adsorbents are summarized in Table 6. Fathy et al. [149] applied the Thomas and Yoon-Nelson models to investigate the adsorption process. The experimental data fit better 
to Thomas's model. The kinetic adsorption of oil by different adsorbents was described well using a pseudo-second-order kinetic model [150]. Eggplant peel was used for cured oil adsorption, and results revealed that the data fit better to the pseudo-second-order kinetic model [151].

Table 6. Adsorption isotherms and kinetics models for the adsorption of contaminants from produced water.

\begin{tabular}{|c|c|c|c|c|}
\hline Pollutant & Adsorbent & Isotherm Models & Kinetic Models & References \\
\hline Oil and organic pollutant & Date pit & Langmuir & - & [120] \\
\hline & Walnut shell & Freundlich & - & \\
\hline Heavy metals & Fruit peel waste & Langmuir & Pseudo-second order & [113] \\
\hline Oil & Pomegranate peel & Langmuir & Pseudo-second order & [118] \\
\hline Oil & Amorphous carbon thin film (palm oil) & - & Thomas model & [149] \\
\hline Oil & Banana peels & Langmuir & Pseudo-second order & [126] \\
\hline Oil & Bentonite, PAC, and DC & Freundlich & - & [124] \\
\hline Oil & Eggshells & - & Pseudo-second order & [125] \\
\hline Oil & Eggplant peel & Langmuir & Pseudo-second order & [151] \\
\hline
\end{tabular}

\section{Recent Progress in the Development of Porous Adsorbent}

Research has been conducted to overcome the shortcomings of conventional adsorbents by synthesizing porous materials that have large pore volumes, good pore size distributions, large surface areas, and regular structures onto zeolites, activated carbon, metal oxide, and mesoporous clay [151,152]. Zeolites have a narrow pore size, whereas metal oxides do not have a large surface area. These materials are not feasible at a large scale because of the stability and leaching of toxic metals into water bodies [153]. Activated carbons and zeolites are hard to synthesize due to the pores' tuning properties. Moreover, they have been used for liquid-phase water treatment due to the large surface area.

\subsection{Metal-Organic Frameworks (MOFs)}

In recent years, MOFs have become one of the most attractive porous crystalline materials, and they have been intensively investigated as an excellent alternative to other methods, given that they can overcome the limitations of conventional porous materials and give promising results in adsorption-related applications [147]. MOFs are a combination of organic and inorganic materials. The history of MOFs dates back to the early 1990s. Kanoo et al. $[139,154]$ developed a coordination polymer, in which a metal node made of copper (I) and an organic linker consisting of nitrogen were used. The synthesized 3D polymer was introduced for the first time to a coordination polymer, which laid the foundation for the advanced development of MOFs. Fujita and Kwon [155] formed a two-dimensional square network composed of cadmium and 4,4' bipyridine. Organic components in this material surrounded the inner cavities. In 1995, Yaghi, Li [156] synthesized a porous material consisting of organic molecules and metal ions. In this study, a newly synthesized material was developed that could tolerate temperatures of up to $350{ }^{\circ} \mathrm{C}$ even after removing the guest molecule. Experimental results proved that the channels were permanent. Yaghi successfully proposed the MOF concept, and this is a landmark in the history of MOF development. Li et al. [157] famously synthesized a highly porous and thermally stable MOF-5 with a large surface area, and successfully stored methane in it. This unique material has now gained the attention of scientists globally for the synthesis of new composites, and for gas storage applications.

\subsection{The Significance of Metal-Organic Frameworks}

Metal-organic frameworks are expected to be the best high-capacity adsorbent due to their high porosity, large surface area, and different configuration and structure. They have several advantageous features, such as great adsorption sites, regular and tunable 
pore structures, functional pore space, and large surface areas. This new class of materials are used in adsorption and have many promising applications, such as catalysis [158,159], drug delivery [160], small molecules sensing gas adsorption [161], and separation [162]. Above all, regeneration and stability are some of the main criteria for the selection of adsorbents. An important advantage of MOFs over traditional adsorbents (such as zeolites and activated carbons) is that the pore environment of the MOFs can be modified, which gives users control over the structural properties that are required for any specific application [163]. Porosity and nanopore diameter are considered to be the key parameters for potential MOF applications because they facilitate the penetration of adsorbed substances to the inner space. MOFs have a great diversity of use due to their inorganic clusters, pore sizes, chemical functionalities, and pore structures.

In the 21st century, nanotechnology has introduced specific, ultrahigh surface area, high-intensity, small-sized nanomaterials to the water industry that have dimensions which range from the sub-nanometers to several hundred nanometers [164,165]. However, the problem with nanoparticles' high surface-to-volume ratio is the intrinsic instability that limits nanoparticles' broad applicability. Different materials, such as zeolites and mesoporous, have been used, but recently MOFs were found to be a better stabilizer. Introducing specific nanoparticles into the permanent porous structure of MOFs results in a more stable material [166]. MOFs act as the precursor or template on which to include nanoparticles, which can fit in their cavities to create a composite made of MOFs and nanoparticles. These hybrid materials have a much lower density and a superior thermal stability [167]. Many efforts have been made to ensure the better fabrication and greater applicability of composites [168-170]. The composites of MOFs and nanoparticles are used as hydrogen storage materials [171,172], catalysts [173], acidic gases adsorbents, ammonia, and as separator in the batteries that are made up of lithium-sulfur. Furthermore, MOFs have been used widely for wastewater treatment. To date, it is rarely used for PW treatment, however. Yet this advanced method is suggested as the future of PW treatment, as shown by the schematic diagram in Figure 7.

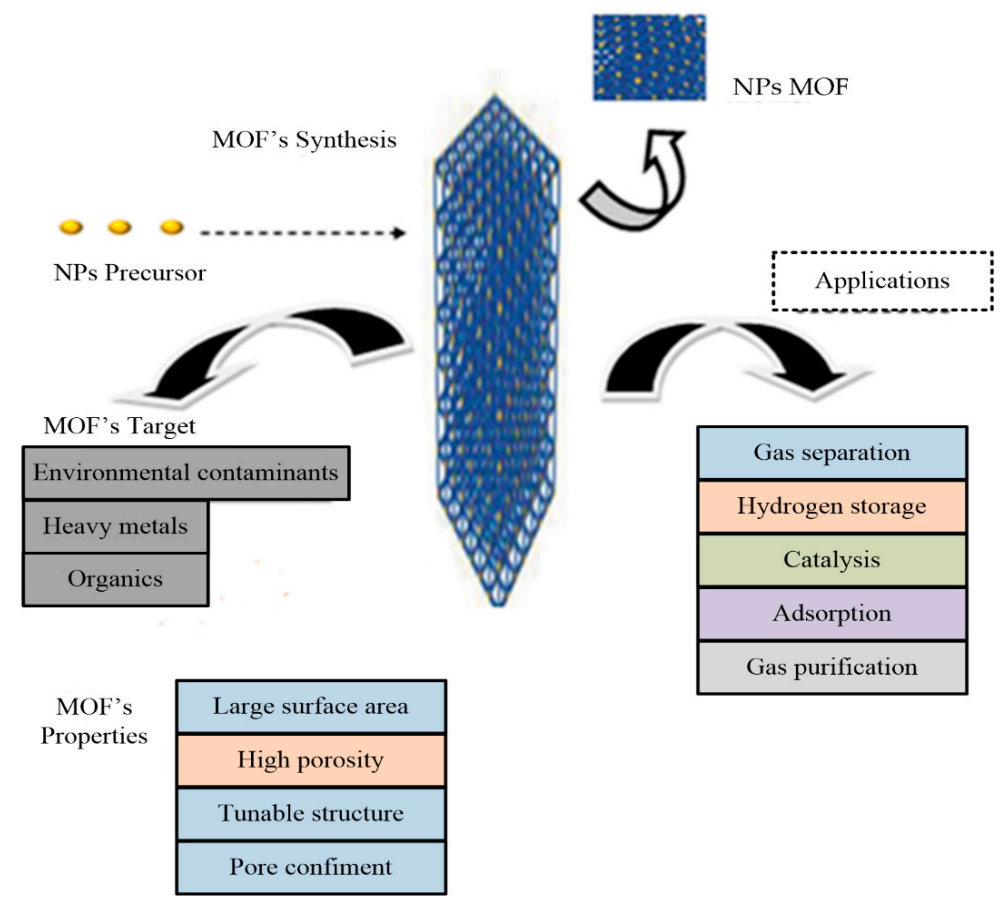

Figure 7. Schematic diagram of MOF properties and applications.

\subsection{Metal-Organic Frameworks as Adsorbents}

MOFs have been widely used for water regeneration and wastewater treatment, and it is highly recommended that they are used for PW treatment in the future. As an 
adsorbent, MOFs are cost effective, with no sludge generation and no additional chemicals required, other than conventional adsorbents. MOFs can regenerate without changing their properties. The current literature on wastewater shows that MOFs provide much better performance than other regular porous materials. Based on these studies, the application of water-based MOFs as an adsorbent in the field of gas or liquid phase adsorptions has been suggested. This will allow a variety of applications of MOFs. Hydrophilic mesoporous compounds were found to be the most favorable of the water-stable MOFs. The water adsorption of porous materials is becoming tremendously important in thermal batteries, water delivery in remote areas, and dehumidification applications. MOFs' structural features, such as excellent BET surface area, topologically large pore volume, size, and the presence of hydrophilic functional groups as adsorption sites, make it very effective for pollutant uptake, especially at low pressures.

Furukawa et al. [174] has identified three criteria that need to be met for MOFs applications to be considered useful:

- Water condensation in the solid pores shows steep uptake behavior.

- Facile desorption and adsorption for energy efficiency and a high uptake capacity for water.

- High water stability and cycling performance.

Furthermore, MOF-based adsorbents have promising applications in adsorbing specific contaminants from water environments, as shown in Table 7. Water-stable MOFs could effectively target compounds in water systems, including dyes, drugs, pharmaceuticals, organic chemicals, and metal ions. MOFs have a superior surface area and more active sites compared to the conventional adsorbent. Nonetheless, MOFs, as porous coordination materials, have excellent chemical stabilities under different harsh conditions that make them well suited for targeted applications. Water-stable MOFs could be one of the most powerful adsorbent materials due to their good chemical stability and their contributions to an energy-efficient and cost-effective separation process.

\subsubsection{Adsorption of Organics}

Water-stable MOFs have the potential to adsorb organics from wastewater. Yang et al. [175] developed fluorous metal-organic frameworks (FMOFs) with superhydrophobicity and which showed significant air and water stability. These FMOFs adsorbed the $\mathrm{C}_{6}-\mathrm{C}_{8}$ hydrocarbons of oil components. Such MOFs can thus be utilized for hydrocarbon storage and cleaning oil spills. Chun et al. [176] developed metal-organic framework for microporous organic network (MOF@MON) hybrid materials that showed exceptional performance in the adsorption of toluene from water. Xie et al. [177] performed a wide-ranging study to screen a series of aluminum-based $\mathrm{MOFs}, \mathrm{CAU}^{-1}$, and MIL-68(Al) for the adsorption of nitrobenzene from water. The MOFs' excellent stability and reusability revealed that they are promising adsorbents for the effective adsorption of organics from wastewater.

Jin et al. $[178,179]$ studied different zirconium-based (ZIF-based) MOFs for the adsorption of 5-hydroxymethylfurfural (HMF). The result showed that HMF uptake at equilibrium increased following in integration of ZIF-93, ZIF-90, and ZIF-8. The results proved that ZIF-8 could be an efficient and reusable adsorbent for HMF recovery from aqueous solutions. Seo et al. [179] used UiO-66 to remove a herbicide and found that UiO-66 had a very high-level adsorption rate, especially with low concentrations of methylchlorophenoxypropionic acid (MCPP) compared to the activated carbon. Electrostatic and $\mathrm{p}-\mathrm{p}$ interactions were essential in the overall adsorption process.

\subsubsection{Adsorption of Heavy Metals}

Inorganic ion removal is essential for two primary reasons:

- Precious metal collection and recovery of these ions can contribute to the progress of their applications in industries.

- As hazardous pollutants, they can have serious negative health effects on human beings and ultimately could be a major global threat to the environment. 
Highly water-stable MOF structures have recently been developed and considered to be robust adsorbents for metal adsorption from wastewater [180,181]. Chowdhury et al. [182] synthesized highly stable and hydrolysis-resistant aluminum-based MOF-GO nanocomposites. The adsorption of As (III), chosen due to low density and high surface area, onto MIL-53(Al) was studied [183]. The results showed that textural properties could be modified by altering the GO to MIL-53(Al) mass ratio. Importantly, MIL-53(Al)-GO has a higher As(III) adsorption capacity compared to individual moieties. A new, thermally stable, 3D MOF, made from cobalt ion, was synthesized by Abbasi et al. [184], and was applied to the adsorption of $\mathrm{Pb}^{2+}, \mathrm{Hg}^{2+}, \mathrm{Al}^{2+}, \mathrm{Fe}^{3+}$, and $\mathrm{Cd}^{2+}$ metal ions from wastewater. This study investigated the effect of exposure time and $\mathrm{pH}$ on metal adsorption. Results showed that maximum removal was achieved for $\mathrm{Fe}^{3+}$ and other metal ions after 80 and $100 \mathrm{~min}$. One of the critical parameters that affects the uptake of metal ions from wastewater is $\mathrm{pH}$, and the highest removal rate of the metals was obtained by when the $\mathrm{pH}$ increased from 2 to 6 . Another study was conducted to synthesize chemically stable and reusable MOF-88 nanoparticles for arsenic adsorption from wastewater [185]. It had a $24.83 \mathrm{mg} / \mathrm{g}$ adsorption capacity. Ke et al. [180] studied a Cu-based MOF for the adsorption of $\mathrm{Hg}^{2+}$ that was functionalized through coordination bonding between the thiol groups of dithioglycol and the CUS of Cu-BTC. The functionalized thiol exhibited a high adsorption capacity (714 $\mathrm{mg} \mathrm{g}^{-1}$ ) for $\mathrm{Hg}^{2+}$, whereas the non-functionalized $\mathrm{Cu}$-BTC had no $\mathrm{Hg}^{2+}$ adsorption capacity under the same experimental conditions. High adsorption on the porous MOF's inner surface was found to be due to the high density of the thiol groups [186,187]. Moreover, a study suggested that MOFs could be used with the ion-exchange method for metal adsorption. It has been observed in a few cases that a simple ion-exchange method leads to the formation of a few iso-structural MOFs [188,189]. Zhu et al. [181] synthesized an iron-based MIL-100(Fe) MOF and found that it could remove arsenic (As). The adsorption of arsenic on MIL-100(Fe) $\mathrm{pH}$ was studied, and the adsorption was reported at a wide $\mathrm{pH}$ range (2-12). The results showed at optimum $\mathrm{pH}$ of 4 , where a $98.2 \%$ removal efficiency rate was achieved, while above $\mathrm{pH} 12$, the efficiency decreased drastically to $35 \%$ because MOF is not stable in basic conditions. No $\mathrm{pH}$ adjustment is needed for neutral water treatment as its $\mathrm{pH}$ ranges between 6-8.5. Arsenic adsorption onto MIL-100(Fe) was six and 36 times superior to iron oxide nanoparticles and commercial iron oxide powders, respectively. Table 7 illustrates the efficiencies of MOF for wastewater treatment.

Table 7. Metal-organic framework for wastewater treatment.

\begin{tabular}{cccc}
\hline MOFs & Pollutants & Removal Efficiency & References \\
\hline MIL-53(Al)-GO & $\mathrm{As}$ (III) & $94.8 \%$ & {$[182]$} \\
\hline & $\mathrm{Pb}^{2+}$ & & \\
3D Cobalt MOF & $\mathrm{Hg}^{2+}$ & - & {$[184]$} \\
& $\mathrm{Al}^{2+}$ & & \\
& $\mathrm{Fe3}$ & & {$[185]$} \\
\hline Cd ${ }^{2+}$ & $80.07 \%$ & {$[181]$} \\
\hline MIL-100(Fe) & $\mathrm{As}$ & $98.2 \%$ & {$[180]$} \\
\hline Cu-BTC & $\mathrm{As}$ & $90.74 \%$ & {$[190]$} \\
\hline MIL-96 & $\mathrm{Hg}{ }^{2+}$ & $80 \%$ & {$[175]$} \\
\hline FMOF-1 & Arsenic & $87.7 \%$ & {$[191]$} \\
\hline ZIF-8 & FMOF-1 & $96.8 \%$ & {$[192]$} \\
\hline UiO-66-NH2@MON & Hydroxymethylfurfura & $87.3 \%$ & {$[179]$} \\
\hline UiO-66 & Toluene & $98.7 \%$ & \\
\hline
\end{tabular}




\section{MOF Recycling}

MOF recycling and reuse is necessary for industrial application. MOF generation requires metal salts, linkers, and solvents. The processing itself is expensive, but organic linkers are the key expense among such consumables. MOF waste recycling depends on its solvent content, thermal and chemical stability, chemical bonding, and structure. The high cost of resources and its toxic and harmful effects on the overall environment could be reduced by recycling the used solvent. MOF recycling is crucial for a sustainable environment, and particularly for energy and resource conservation. Recycling MOFs contains three steps: waste MOF collection, processing, and the production of new products [193-195]. Recycling MOFs can reduce waste generation, prevent pollution, and provide economic security. Cost-effective adsorption and desorption are the fundamental characteristics of good adsorbent material. The regeneration of the adsorbent helps to improve the economic feasibility of the process and enhances the possibility of using the adsorbents on a commercial scale. During massive adsorption-desorption regeneration, cyclic stability is an important parameter to determine the lifespan of the MOF and decide whether it should be replaced in the adsorption plant. After the multi-stage cycle, the adsorbent's sorption capacity should not be reduced, nor should it change its structure and properties. Thermogravimetric methods are frequently used to determine adsorbent sorption capacity, renewability, and stability. Only the guest molecules could be removed from a porous framework during regeneration while keeping the structures intact through activation. During activation, accessible pores and open metal sites are produced to improve how the guest molecules interact with the host in MOFs. Ideally, the MOF's structural and chemical properties must be retained during the regeneration and reuse process.

\section{Future Research Perspectives}

The upward flow of a large volume of PW during oil and gas production is becoming a major problem for the oil and gas industries. PW is highly polluted with immiscible oil, organic compounds, heavy metals, salts, suspended solids, and radioactive waste, which need to be removed from PW on site before letting it enter the environment. Based on the literature reviewed, the conventional treatment methods display poor performance and have other significant limitations, such as prolonged treatment time, vast land requirements, and high capital costs. Most importantly, the traditional treatment approaches produce secondary pollutants which need further treatment, making the conventional process less attractive in the long run. The most attractive and feasible treatment approach could be adsorption, but only if the challenges faced by this technology are overcome. Its efficacy has been proven in previous studies. However, the adsorbents used in adsorption studies require a critical assessment. Adsorption provides a cheaper alternative for the remediation of PW.

Nevertheless, the factors affecting the performance of adsorbents, such as surface area, adsorbent dosage, treatment temperature, contact time, and $\mathrm{pH}$, to name a few, need to be controlled and optimized to maximize PW treatment efficiency. MOFs are understood to offer better alternatives for PW water treatment than traditional adsorbents. For example, MOFs can tolerate high temperatures and provide a large surface area, and have greater porosity and better nanopore diameters. It is suggested that highly porous and new hybrid MOFs could be developed and used for PW treatment in large-scale applications. Since the $\mathrm{PW}$ is contaminated with various organic and inorganic compounds, future research should produce MOFs that simultaneously remove multiple contaminants. Future studies should also consider the regeneration of MOFs at low temperatures, reducing the overall cost of PW treatment. New routes for synthesizing MOFs could consider eliminating the need for expensive chemicals and solvents and move towards a green and sustainable process.

\section{Conclusions}

Adsorption performed an essential role in removing contaminants. As a result, it has been the focus of significant amounts of attention in both scientific research and commercial applications. This review has summarized the currently investigated conventional and 
non-conventional adsorbents for PW contaminates. Since PW generation is a fundamental problem, more investigation is required to develop techniques to reduce PW volumes. Studies on adsorption for PW treatment are limited, and there is a lack of a comprehensive understanding regarding adsorption applicability and the strategies to improve the treatment efficacy. The most attractive and feasible treatment approach could be adsorption, if the challenges faced by this technology are overcome. The safest technology for treating PW depends on its chemistry, cost effectiveness, space availability, reuse and discharge plans, durable operation, and byproducts. Furthermore, the development of highly porous, efficient, eco-friendly, cost-effective, mechanically stable, and sustainable adsorbents is the main concern for adsorption to overcome its limitations, which include low surface areas and restrictions on reuse and regeneration, and which limit its application at a large scale. Ideal adsorbents will minimize stress on freshwater resources, and have a range of positive features, including availability, non-toxicity, cost, metal-binding capacity, and regeneration as part of their application in PW treatment. This is particularly important for water-stressed countries, where population and economic growth continue to increase stress on the region's limited water resources.

Author Contributions: Conceptualization, H.G.Z. and L.B.; Supervision, L.B. and R.P; Writing—original draft preparation, H.G.Z.; writing—review and editing, P.K.S., S.U.I. and S.R.M.K.; Funding acquisition, L.B. All authors have read and agreed to the published version of the manuscript.

Funding: YUTP grant with cost center 015LCO-303.

Data Availability Statement: Not applicable.

Acknowledgments: This work is supported by the Civil Engineering Department of Universiti Teknologi PETRONAS.

Conflicts of Interest: The authors declare no conflict of interest.

$\begin{array}{ll}\text { Abbreviations } \\ \text { Ac } & \text { Actinium } \\ \text { BOD } & \text { Biological oxygen demand } \\ \text { Cd } & \text { Cadmium } \\ \text { COD } & \text { Chemical oxygen demand } \\ \text { Cr } & \text { Chromium } \\ \text { Cu } & \text { Copper } \\ \text { DC } & \text { Deposited carbon } \\ \text { EG } & \text { Exfoliated graphite } \\ \text { FMOFs } & \text { Fluorous metal-organic frameworks } \\ \text { GM } & \text { Graphene magnetite } \\ \text { GN } & \text { Graphene nanoplatelets } \\ \text { HMF } & \text { Hydroxymethylfurfural } \\ \text { KW } & \text { Kiwi } \\ \text { MCPP } & \text { Methylchlorophenoxypropionic acid } \\ \text { MOFs } & \text { Metal-organic frameworks } \\ \text { NPD } & \text { Naphthalene, phenanthrene, dibenzothiophene } \\ \text { OIW } & \text { Non-polar oil in water } \\ \text { PAC } & \text { Powdered activated carbon } \\ \text { PPP } & \text { Pomegranate peel powder } \\ \text { PZC } & \text { Point of zero charge } \\ \text { Ra } & \text { Radium } \\ \text { TDS } & \text { Total dissolved solids } \\ \text { TENORM } & \text { Technologically enhanced naturally occurring radioactive materials } \\ \text { TOC } & \text { Total organic carbon } \\ \end{array}$




$\begin{array}{ll}\text { TSS } & \text { Total suspended solids } \\ \text { TOC } & \text { Total organic carbon } \\ \text { WS } & \text { Walnut shell } \\ \text { Zn } & \text { Zinc }\end{array}$

\section{References}

1. Abd El-Ghaffar, M.; Abdel-Wahab, Z.; Elwakeel, K. Extraction and separation studies of silver (I) and copper (II) from their aqueous solution using chemically modified melamine resins. Hydrometallurgy 2009, 96, 27-34. [CrossRef]

2. Bayati, F.; Shayegan, J.; Noorjahan, A. Treatment of oilfield produced water by dissolved air precipitation/solvent sublation. J. Pet. Sci. Eng. 2011, 80, 26-31. [CrossRef]

3. Kabyl, A.; Yang, M.; Abbassi, R.; Li, S. A risk-based approach to produced water management in offshore oil and gas operations. Process. Saf. Environ. Prot. 2020, 139, 341-361. [CrossRef]

4. Energy Outlook. International Energy Outlook. In Outlook; Washington, DC, USA. 2010. Available online: https://www.eia. gov/outlooks/ieo/index.php (accessed on 10 October 2021).

5. Hu, L.; Yu, J.; Luo, H.; Wang, H.; Xu, P.; Zhang, Y. Simultaneous recovery of ammonium, potassium and magnesium from produced water by struvite precipitation. Chem. Eng. J. 2020, 382, 123001. [CrossRef]

6. Al-Ghouti, M.A.; Al-Kaabi, M.A.; Ashfaq, M.Y.; Da'Na, D.A. Produced water characteristics, treatment and reuse: A review. J. Water Process. Eng. 2019, 28, 222-239. [CrossRef]

7. Haneef, T.; Ul Mustafa, M.R.; Rasool, K.; Ho, Y.C.; Mohamed Kutty, S.R. Removal of polycyclic aromatic hydrocarbons in a heterogeneous Fenton like oxidation system using nanoscale zero-valent iron as a catalyst. Water 2020, 12, 2430. [CrossRef]

8. Azetsu-Scott, K.; Yeats, P.; Wohlgeschaffen, G.; Dalziel, J.; Niven, S.; Lee, K. Precipitation of heavy metals in produced water: Influence on contaminant transport and toxicity. Mar. Environ. Res. 2007, 63, 146-167. [CrossRef] [PubMed]

9. Hayes, T.; Arthur, D. Overview of Emerging Produced Water Treatment Technologies. In Proceedings of the 11th Annual International Petroleum Environmental Conference, Albuquerque, NM, USA, 12-15 October 2004.

10. Estrada, J.M.; Bhamidimarri, R. A review of the issues and treatment options for wastewater from shale gas extraction by hydraulic fracturing. Fuel 2016, 182, 292-303. [CrossRef]

11. Rahman, A.; Agrawal, S.; Nawaz, T.; Pan, S.; Selvaratnam, T. A review of algae-based produced water treatment for biomass and biofuel production. Water 2020, 12, 2351. [CrossRef]

12. Chen, L.; Xu, Q.; Gossage, J.L.; Lou, H.H. Simulation and economic evaluation of a coupled thermal vapor compression desalination process for produced water management. J. Nat. Gas Sci. Eng. 2016, 36, 442-453. [CrossRef]

13. Fakhru'L-Razi, A.; Pendashteh, A.; Abdullah, L.C.; Biak, D.R.A.; Madaeni, S.S.; Abidin, Z.Z. Review of technologies for oil and gas produced water treatment. J. Hazard. Mater. 2009, 170, 530-551. [CrossRef] [PubMed]

14. Igunnu, E.T.; Chen, G.Z. Produced water treatment technologies. Int. J. Low-Carbon Technol. 2014, 9, 157-177. [CrossRef]

15. Rezakazemi, M.; Amooghin, A.E.; Montazer-Rahmati, M.M.; Ismail, A.F.; Matsuura, T. State-of-the-art membrane based CO 2 separation using mixed matrix membranes (MMMs): An overview on current status and future directions. Prog. Polym. Sci. 2014, 39, 817-861. [CrossRef]

16. Younas, M.; Rezakazemi, M.; Daud, M.; Wazir, M.B.; Ahmad, S.; Ullah, N.; Inamuddin; Ramakrishna, S. Recent progress and remaining challenges in post-combustion CO2 capture using metal-organic frameworks (MOFs). Prog. Energy Combust. Sci. 2020, 80, 100849. [CrossRef]

17. Roushani, M.; Saedi, Z.; Baghelani, Y.M. Removal of cadmium ions from aqueous solutions using TMU-16-NH2 metal organic framework. Environ. Nanotechnol. Monit. Manag. 2017, 7, 89-96.

18. Gulzamana, H.; Baloo, L. Design Expert Application in the Optimization of Cadmium (II) by Chitosan from Produced water. Ann. Rom. Soc. Cell Biol. 2021, 25, 4687-4695.

19. Ghosh, D.; Saha, R.; Ghosh, A.; Nandi, R.; Saha, B. A review on toxic cadmium biosorption from contaminated wastewater. Desalin. Water Treat. 2015, 53, 413-420. [CrossRef]

20. NPC. Management of Produced Water from Oil and Gas Wells. National Petroleum Council. Available online: https://www.npc org/Prudent_Development-Topic_Papers/2-17_Management_of_Produced_Water_Paper.pdf (accessed on 6 November 2021).

21. Hoelzer, K.; Sumner, A.; Karatum, O.; Nelson, R.; Drollette, B.D.; O'Connor, M.P.; D’ Ambro, E.L.; Getzinger, G.; Ferguson, P.L.; Reddy, C.M.; et al. Indications of transformation products from hydraulic fracturing additives in shale-gas wastewater. Environ. Sci. Technol. 2016, 50, 8036-8048. [CrossRef]

22. Lee, K.; Cobanli, S.E.; Robinson, B.J.; Wohlgeschaffen, G. Application of Microbiological Methods to Assess the Potential Impact of Produced Water Discharges. In Produced Water: Environmental Risks and Mitigation Technologies; Springer Publishing: New York, NY, USA, 2011.

23. Benko, K.L.; Drewes, J.E. Produced water in the Western United States: Geographical distribution, occurrence, and composition. Environ. Eng. Sci. 2008, 25, 239-246. [CrossRef]

24. Faber, A.-H.; Annevelink, M.; Gilissen, H.K.; Schot, P.; van Rijswick, M.; de Voogt, P.; van Wezel, A. How to Adapt Chemical Risk Assessment for Unconventional Hydrocarbon Extraction Related to the Water System. In Reviews of Environmental Contamination and Toxicology; Springer: Singapore, 2017; Volume 246, pp. 1-32. 
25. Jiménez, S.; Andreozzi, M.; Micó, M.M.; Alvarez, M.G.; Contreras, S. Produced water treatment by advanced oxidation processes. Sci. Total Environ. 2019, 666, 12-21. [CrossRef] [PubMed]

26. Eriksen, D.Ø.; Sidhu, R.; Strålberg, E.; Iden, K.I.; Hylland, K.; Ruus, A.; Rye, H. Radionuclides in produced water from Norwegian oil and gas installations-Concentrations and bioavailability. Czechoslov. J. Phys. 2006, 56, D43-D48. [CrossRef]

27. Hamlat, M.; Djeffal, S.; Kadi, H. Assessment of radiation exposures from naturally occurring radioactive materials in the oil and gas industry. Appl. Radiat. Isot. 2001, 55, 141-146. [CrossRef]

28. Othman, I.M.E.-S.A.; Saleh, I.H.; Ghatass, Z.F.; Metwally, M.A.-A. Radiological Risk Assessment in a Type of Complex Petroleum Refinery in Egypt. Arab. J. Nucl. Sci. Appl. 2018, 51, 31-43. [CrossRef]

29. Kh, K.H. Research into the radionuclide pollution of ecosystem on the territory of oil fields of Absheron peninsula. Kim. Probl. 2016, 3, 233-237.

30. Shawky, S.; Amer, H.; Nada, A.; El-Maksoud, T.A.; Ibrahiem, N. Characteristics of NORM in the oil industry from Eastern and Western deserts of Egypt. Appl. Radiat. Isot. 2001, 55, 135-139. [CrossRef]

31. Ali, M.M.; Zhao, H.; Li, Z.; Ayoub, A.A. A review about radioactivity in TENORMs of produced water waste from petroleum industry and its environmental and health effects. EES 2020, 467, 012120. [CrossRef]

32. McDevitt, B.; McLaughlin, M.; Cravotta, C.A.; Ajemigbitse, M.A.; Van Sice, K.J.; Blotevogel, J.; Borch, T.; Warner, N.R. Emerging investigator series: Radium accumulation in carbonate river sediments at oil and gas produced water discharges: Implications for beneficial use as disposal management. Environ. Sci. Process. Impacts 2019, 21, 324-338. [CrossRef]

33. Kraemer, T.F.; Reid, D.F. The occurrence and behavior of radium in saline formation water of the U.S. Gulf Coast region. Chem. Geol. 1984, 46, 153-174. [CrossRef]

34. Jodłowski, P.; Macuda, J.; Nowak, J.; Dinh, C.N. Radioactivity in wastes generated from shale gas exploration and production-North-Eastern Poland. J. Environ. Radioact. 2017, 175, 34-38. [CrossRef] [PubMed]

35. Lagera, L.; Hart, A.; Graham, B. Radionuclides in Oil and gas Operational Discharges and Environmental Samples Associated with Offshore Oil and gas Production Facilities. In Radionuclides, Metals, and Hydrocarbons in Oil and Gas Operational Discharges and Environmental Samples Associated with Offshore Production Facilities on the Texas/Louisiana Continental Shelf with an Environmental Assessment of Metals and Hydrocarbons; Prepared for US Department of Energy; Continental Shelf Associates, Inc.: Jupiter, FL, USA, 1999. Available online: https:/ / www.osti.gov/servlets/purl/9730\#page=96 (accessed on 10 October 2021).

36. Gaefvert, T.; Færevik, I. Natural Radioactivity in Produced Water from the Norwegian Oil and Gas Industry in 2003; Statens Straalevern: Oesteraas, Norway, 2005.

37. Kpeglo, D.O. Radiation Exposure to Natural Radioactivity in Crude Oil and Petroleum Waste from Oil Fields in Ghana; Modelling Risk Assessment and Regulatory Control. Ph.D. Thesis, University of Ghana, Accra, Ghana, 2015.

38. Agbalagba, E.; Avwiri, G.; Ononugbo, C. Activity concentration and radiological impact assessment of 226Ra, 228Ra and 40K in drinking waters from (OML) 30, 58 and 61 oil fields and host communities in Niger Delta region of Nigeria. J. Environ. Radioact. 2013, 116, 197-200. [CrossRef]

39. Avwiri Gregory, O.; Emmanuel, E.; Ezekiel, O.A. Gamma spectroscopy analysis of produced water from selected flow stations in delta state, Nigeria. Int. J. Environ. Monit. Anal. 2013, 1, 167-174.

40. Parmaksız, A.; Ağuş, Y.; Bulgurlu, F.; Bulur, E.; Öncü, T.; Özkök, Y. Measurement of enhanced radium isotopes in oil production wastes in Turkey. J. Environ. Radioact. 2015, 141, 82-89. [CrossRef] [PubMed]

41. Faanu, A.; Ephraim, J.H.; Darko, E.O. Assessment of public exposure to naturally occurring radioactive materials from mining and mineral processing activities of Tarkwa Goldmine in Ghana. Environ. Monit. Assess. 2011, 180, 15-29. [CrossRef] [PubMed]

42. Canoba, A.; Gnoni, G.; Truppa, W.; Nuclear, A.R. Norm measurements in the oil and gas industry in Argentina. In PARTE I. 2007. Available online: https:/ / www.argentina.gob.ar/sites/default/files/mt_2007a.pdf\#page=34 (accessed on 10 October 2021).

43. Pillay, A.E.; Salih, F.M.; Maleek, M.I. Radioactivity in oily sludge and produced waste water from oil: Environmental concerns and potential remedial measures. Sustainability 2010, 2, 890-901. [CrossRef]

44. Khadhim, N.F.; Adnan, O.H. Measurement of natural radioactivity in Al-Dora Refinery by using (HPGe) detector. Adv. Appl. Sci. Res. 2016, 7, 197-208.

45. Ali, K.K.; Shafik, S.S.; Husain, H.A. Radiological Assessment of NORM Resulting From Oil and Gas Production Processing in South Rumaila Oil Field, Southern Iraq. Iraqi J. Sci. 2017, 58, 1037-1050.

46. Moatar, F.; Shadizadeh, S.R.; Karbassi, A.R.; Ardalani, E.; Derakhshi, R.A.; Asadi, M. Determination of naturally occurring radioactive materials (NORM) in formation water during oil exploration. J. Radioanal. Nucl. Chem. 2010, 283, 3-7. [CrossRef]

47. Botezatu, E.; Grecea, C. Radiological impact assessment on behalf of Oil/Gas Industry. J. Prev. Med. 2004, 12, 16-21.

48. Zakaria, K.M. Radiological Impacts of Norm and Poly Aromatic Hydrocarbon in Petroleum Industry Process on Marine Ecosystem at the Red Sea, Egypt. Environ. Anal. Ecol. Stud. 2018, 1. [CrossRef]

49. Testa, C.; Desideri, D.; Meli, M.A.; Roselli, C.; Bassignani, A.; Colombo, G.; Fantoni, R.F. Radiation protection and radioactive scales in oil and gas production. Health Phys. 1994, 67, 34-38. [CrossRef] [PubMed]

50. Otton, J.K. Environmental Aspects of Produced-Water Salt Releases in Onshore and Coastal Petroleum-Producing Areas of the Conterminous US-A Bibliography; USGS Publication Warehouse; US Geological Survey: Reston, VA, USA, 2006. Available online: https: / / pubs.er.usgs.gov/publication/ ofr20061154 (accessed on 6 November 2021). 
51. Hedar, Y. Pollution Impact and Alternative Treatment for Produced Water. In Proceedings of the 2nd International Conference on Energy, Environmental and Information System (ICENIS 2017), Semarang, Indonesia, 15-16 August 2018; Volume 31, p. 03004. [CrossRef]

52. Jiménez, S.; Micó, M.M.; Arnaldos, M.; Medina, F.; Contreras, S. State of the art of produced water treatment. Chemosphere 2018, 192, 186-208. [CrossRef] [PubMed]

53. Bostick, D.T. Characterization of Soluble Organics in Produced Water; ORNL Oak Ridge National Laboratory (US): Oak Ridge, TN, USA, 2002. Available online: https:/ / www.osti.gov/biblio/814231 (accessed on 10 October 2021).

54. Krause, P. Spatial and temporal variability in receiving water toxicity near an oil effluent discharge site. Arch. Environ. Contam. Toxicol. 1995, 29, 523-529. [CrossRef]

55. Guerra, K.; Dahm, K.; Dundorf, S. Oil and Gas Produced Water Management and Beneficial Use in the Western United States; US Department of the Interior, Bureau of Reclamation: Denver, CO, USA, 2011. Available online: https://www.usbr.gov/research/ dwpr/reportpdfs/report157.pdf (accessed on 10 October 2021).

56. Gazali, A.K. Environmental Impact opf Produced Water and Drilling Waste Discharges from the Niger Delta Petroleum Industry. IOSR J. Eng. 2017, 7, 22-29. [CrossRef]

57. Neff, J.; Lee, K.; DeBlois, E.M. Produced Water: Overview of Composition, Fates, and Effects. In Produced Water; Springer: Springer, 2011; pp. 3-54.

58. Neff, J.M. Bioaccumulation in Marine Organisms: Effect of Contaminants from Oil Well Produced Water; Elsevier: Amsterdam, The Netherlands, 2002.

59. Elias-Samlalsingh, N.; Agard, J.B. Application of toxicity identification evaluation procedures for characterizing produced water using the tropical mysid, Metamysidopsis insularis. Environ. Toxicol. Chem. Int. J. 2004, 23, 1194-1203. [CrossRef]

60. Schifter, I.; González-Macías, C.; Salazar-Coria, L.; Sánchez-Reyna, G.; González-Lozano, C. Long-term effects of discharges of produced water the marine environment from petroleum-related activities at Sonda de Campeche, Gulf of México. Environ. Monit. Assess. 2015, 187, 723. [CrossRef]

61. Taqi, A.; Al-Ani, L.A.A.; Ali, A.M. Assessment of the natural radioactivity levels in Kirkuk oil field. J. Radiat. Res. Appl. Sci. 2016, 9, 337-344. [CrossRef]

62. Mountford, P.; Temperton, D. Recommendations of the International Commission on Radiological Protection (ICRP) 1990; Springer: Berlin/Heidelberg, Germany, 1992.

63. Taheri, A.; Taheri, A.; Fathivand, A.A.; Mansouri, N. Risk assessment of naturally occurring radioactive materials (NORM) in the hydrocarbon sludge extracted from the south pars gas field in Iran. Process. Saf. Environ. Prot. 2019, 125, 102-120. [CrossRef]

64. Ali, M.M.; Zhao, H.; Li, Z.; Maglas, N.N. Concentrations of TENORMs in the petroleum industry and their environmental and health effects. RSC Adv. 2019, 9, 39201-39229. [CrossRef]

65. Abo-Elmagd, M.; Soliman, H.; Salman, K.; El-Masry, N. Radiological hazards of TENORM in the wasted petroleum pipes. J. Environ. Radioact. 2009, 101, 51-54. [CrossRef] [PubMed]

66. Al-Saleh, F.; Al-Harshan, G. Measurements of radiation level in petroleum products and wastes in Riyadh City Refinery. J. Environ. Radioact. 2008, 99, 1026-1031. [CrossRef] [PubMed]

67. Olobatoke, R.Y.; Mathuthu, M. Radionuclide exposure in animals and the public health implications. Turk. J. Vet. Anim. Sci. 2015, 39, 381-388. [CrossRef]

68. Masindi, V.; Muedi, K.L. Environmental Contamination by Heavy Metals. Heavy Met. 2018, 10, 115-132.

69. Grant, A.; Briggs, A.D. Toxicity of sediments from around a North Sea oil platform: Are metals or hydrocarbons responsible for ecological impacts? Mar. Environ. Res. 2002, 53, 95-116. [CrossRef]

70. Somma, S.; Reverchon, E.; Baldino, L. Water Purification of Classical and Emerging Organic Pollutants: An Extensive Review. ChemEngineering 2021, 5, 47. [CrossRef]

71. Holdway, D.A. The acute and chronic effects of wastes associated with offshore oil and gas production on temperate and tropical marine ecological processes. Mar. Pollut. Bull. 2002, 44, 185-203. [CrossRef]

72. Ahmad, F.; Morris, K.; Law, G.T.W.; Taylor, K.G.; Shaw, S. Fate of radium on the discharge of oil and gas produced water to the marine environment. Chemosphere 2021, 273, 129550. [CrossRef]

73. McCormack, P. Analysis of oilfield produced waters and production chemicals by electrospray ionisation multi-stage mass spectrometry (ESI-MSn). Water Res. 2001, 35, 3567-3578. [CrossRef]

74. Veil, J. US Produced Water Volumes and Management Practices in 2012; Groundwater Protection Council: Oklahoma City, OK, USA, 2015.

75. Sweet, D. Energy in the United States: An Industry Analysis; Appalachian State University: Boone, NC, USA, 2020.

76. Lin, L.; Jiang, W.; Chen, L.; Xu, P.; Wang, H. Treatment of Produced Water with Photocatalysis: Recent Advances, Affecting Factors and Future Research Prospects. Catalysts 2020, 10, 924. [CrossRef]

77. Mondal, S.; Wickramasinghe, S.R. Produced water treatment by nanofiltration and reverse osmosis membranes. J. Membr. Sci. 2008, 322, 162-170. [CrossRef]

78. Khatib, Z.; Verbeek, P. Water to Value-Produced Water Management for Sustainable Field Development of Mature and Green Fields. J. Pet. Technol. 2003, 55, 26-28. [CrossRef]

79. Burnett, D.B.; Siddiqui, M. Recovery of Fresh Water Resources from Desalination of Brine Produced during Oil and Gas Production Operations; Texas Engineering Experiment Station: College Station, TX, USA, 2006. [CrossRef] 
80. Wang, Z.; Gong, Z.; Wang, Z.; Li, X.; Chu, Z. Application and development of pyrolysis technology in petroleum oily sludge treatment. Environ. Eng. Res. 2020, 26, 190460. [CrossRef]

81. Al-abri, O.H.; Lakkimsetty, N.R.; Shaik, F. pretreatment of oil produced water using low cost adsorbents. Int. J. of Mech. Prod. Eng. Res. Dev. IJMPERD 2020, 10, 2435-2444.

82. United States Environmental Protection Agency. Oil and Gas Extraction Effluent Guidelines; EPA: Washington, DC, USA, 2019. Available online: https:/ / www.epa.gov/eg/oiland-gas-extraction-effluent-guidelines (accessed on 20 November 2021).

83. Clark, C.E.; Veil, J.A. Produced Water Volumes and Management Practices in the United States; Argonne National Lab.(ANL): Argonne, IL, USA, 2009.

84. Muherei, M.; Junin, R. Potential of surfactant washing to solve drilling waste environmental problems off shore. J. Eng. Res. 2007, 12, 1-10.

85. CAPP. Technical Report: Offshore Produced Water Waste Management. CAPP (Canadian Association of Petroleum). Available online: http:/ / www.capp.ca (accessed on 19 November 2021).

86. Hildenbrand, Z.L.; Santos, I.; Liden, T.; Carlton, D.D.; Varona-Torres, E.; Martin, M.S.; Reyes, M.L.; Mulla, S.R.; Schug, K.A. Characterizing variable biogeochemical changes during the treatment of produced oilfield waste. Sci. Total Environ. 2018, 634, 1519-1529. [CrossRef] [PubMed]

87. Thompson, A.W.; Prokopy, L.S. Tracking urban sprawl: Using spatial data to inform farmland preservation policy. Land Use Policy 2009, 26, 194-202. [CrossRef]

88. Sheikholeslami, Z.; Kebria, D.Y.; Qaderi, F. Nanoparticle for degradation of BTEX in produced water; an experimental procedure. J. Mol. Liq. 2018, 264, 476-482. [CrossRef]

89. Drewes, J.E.; Cath, T.Y.; Xu, P.; Graydon, J.; Veil, J.; Snyder, S. An Integrated Framework for Treatment and Management of Produced Water; RPSEA Project; 2009; p. 07122-12. Available online: http:/ / aqwatec.mines.edu/research/projects/Tech_Assessment_PW_ Treatment_Tech.pdf (accessed on 10 October 2021).

90. Li, Y.S.; Yan, L.; Xiang, C.B.; Hong, L.J. Treatment of oily wastewater by organic-inorganic composite tubular ultrafiltration (UF) membranes. Desalination 2006, 196, 76-83. [CrossRef]

91. Lusinier, N.; Seyssiecq, I.; Sambusiti, C.; Jacob, M.; Lesage, N.; Roche, N. Biological Treatments of Oilfield Produced Water: A Comprehensive Review. SPE J. 2019, 24, 2135-2147. [CrossRef]

92. Qu, F.; Zhu, L.; Yang, K. Adsorption behaviors of volatile organic compounds (VOCs) on porous clay heterostructures (PCH). J. Hazard. Mater. 2009, 170, 7-12. [CrossRef] [PubMed]

93. Daigle, T.P.; Cox, L.D. Ultra deep water discharge of produced water and/or solids at the seabed. In Research Partnership to Secure Energy for America (RPSEA); USA. 2016. Available online: www.rpsea.org (accessed on 10 October 2021).

94. Abesekara, M.S.; Kosvinna, K.N.R.; Amarasinghe, B. Adsorption and desorption studies of Ni2+ ions on to coconut shell char. In Proceedings of the 2nd International Symposium on Water Pollution and Treatment, Bangkok, Thailand, 17-18 October 2019; Volume 427, p. 012005. [CrossRef]

95. Ayob, S.; Othman, N.; Altowayti, W.A.H.; Khalid, F.S.; Abu Bakar, N.; Tahir, M.; Soedjono, E.S. A Review on Adsorption of Heavy Metals from Wood-Industrial Wastewater by Oil Palm Waste. J. Ecol. Eng. 2021, 22, 249-265. [CrossRef]

96. Mathew, B.B.; Jaishankar, M.; Biju, V.G.; Beeregowda, K.N. Role of Bioadsorbents in Reducing Toxic Metals. J. Toxicol. 2016, 2016, 4369604. [CrossRef]

97. Sims, R.A.; Harmer, S.L.; Quinton, J.S. The role of physisorption and chemisorption in the oscillatory adsorption of organosilanes on aluminium oxide. Polymers 2019, 11, 410. [CrossRef] [PubMed]

98. Olanipekun, O.; Oyefusi, A.; Neelgund, G.M.; Oki, A. Adsorption of lead over graphite oxide. Spectrochim. Acta Part A Mol. Biomol. Spectrosc. 2014, 118, 857-860. [CrossRef]

99. Lasheen, M.; El-Sherif, I.Y.; El-Wakeel, S.T.; Sabry, D.Y.; El-Shahat, M.F. Heavy metals removal from aqueous solution using magnetite Dowex 50WX4 resin nanocomposite. JMES 2017, 8, 503-511.

100. Doyle, D.; Brown, A. Produced water treatment and hydrocarbon removal with organoclay. In Proceedings of the SPE Annual Technical Conference and Exhibition, Society of Petroleum Engineers, Dallas, TX, USA, 1-4 October 2000. [CrossRef]

101. Carvalho, M.; Clarisse, M.; Lucas, E.; Barbosa, C.; Barbosa, L. Evaluation of the polymeric materials (DVB copolymers) for produced water treatment. In Proceedings of the International Petroleum Exhibition and Conference, Abu Dhabi, United Arab Emirates, 13-16 October 2002.

102. Janks, J.S.; Cadena, F. Investigations into the Use of Modified Zeolites for Removing Benzene, Toluene, and Xylene from Saline Produced Water. In Produced Water; Springer: Singapore, 1992; pp. 473-487.

103. Arthur, J.D.; Langhus, B.G.; Patel, C. Technical Summary of Oil \& Gas Produced Water Treatment Technologies; All Consulting, LLC: Tulsa, Oklahoma, 2005.

104. Elsayed, A.E.; Osman, D.I.; Attia, S.K.; Ahmed, H.M.; Shoukry, E.M.; Mostafa, Y.M.; Taman, A.R. A study on the removal characteristics of organic and inorganic pollutants from wastewater by low cost biosorbent. Egypt. J. Chem. 2020, 63, 1429-1442. [CrossRef]

105. Imamoglu, M.; Tekir, O. Removal of copper (II) and lead (II) ions from aqueous solutions by adsorption on activated carbon from a new precursor hazelnut husks. Desalination 2008, 228, 108-113. [CrossRef]

106. Krishnan, K.A.; Anirudhan, T. Removal of cadmium(II) from aqueous solutions by steam-activated sulphurised carbon prepared from sugar-cane bagasse pith: Kinetics and equilibrium studies. Water SA 2003, 29, 147-156. [CrossRef] 
107. Gusain, R.; Kumar, N.; Ray, S.S. Recent advances in carbon nanomaterial-based adsorbents for water purification. Coord. Chem. Rev. 2020, 405, 213111. [CrossRef]

108. Renugadevi, N.; Sangeetha, R.; Lalitha, P. Kinetics of the adsorption of methylene blue from an industrial dyeing effluent onto activated carbon prepared from the fruits of Mimusops elengi. Arch. Appl. Sci. Res. 2011, 3, 492-498.

109. Abechi, E.; Gimba, C.E.; Uzairu, A.; Kagbu, J.A. Kinetics of adsorption of methylene blue onto activated carbon prepared from palm kernel shell. Arch. Appl. Sci. Res. 2011, 3, 154-164.

110. Ghane Ghanad, I. Atmospheric Leaching of Enargite in Iron Sulfate Solutions Catalyzed by Activated Carbon. Ph.D. Thesis, University of British Columbia, Vancouver, BC, Cananda, 2011.

111. Li, X.; Chen, S.; Fan, X.; Quan, X.; Tan, F.; Zhang, Y.; Gao, J. Adsorption of ciprofloxacin, bisphenol and 2-chlorophenol on electrospun carbon nanofibers: In comparison with powder activated carbon. J. Colloid Interface Sci. 2015, 447, 120-127. [CrossRef]

112. Matsui, M.; Kiyozumi, Y.; Yamamoto, T.; Mizushina, Y.; Mizukami, F.; Sakaguchi, K. Selective adsorption of biopolymers on zeolites. Chem. A Eur. J. 2001, 7, 1555-1560. [CrossRef]

113. Pathak, P.; Mandavgane, S.; Kulkarni, B.D. Fruit peel waste as a novel low-cost bio adsorbent. Rev. Chem. Eng. 2015, 31, 361-381. [CrossRef]

114. Mahmudi, M.; Arsad, S.; Amalia, M.C.; Rohmaningsih, H.A.; Prasetiya, F.S. An Alternative Activated Carbon from Agricultural Waste on Chromium Removal. J. Ecol. Eng. 2020, 21, 1-9. [CrossRef]

115. Bhatnagar, A.; Minocha, A. Adsorptive removal of 2,4-dichlorophenol from water utilizing Punica granatum peel waste and stabilization with cement. J. Hazard. Mater. 2009, 168, 1111-1117. [CrossRef]

116. Fillo, J.P.; Koraido, S.M.; Evans, J.M. Sources, Characteristics, and Management of Produced Waters from Natural Gas Production and Storage Operations. In Produced Water; Springer: Singapore, 1992; pp. 151-161.

117. Johnson, B.M.; Kanagy, L.E.; Rodgers Jr, J.H.; Castle, J.W. Feasibility of a pilot-scale hybrid constructed wetland treatment system for simulated natural gas storage produced waters. Environ. Geosci. 2008, 15, 91-104. [CrossRef]

118. Ibrahim, T.H.; Gulistan, A.S.; Khamis, M.I.; Ahmed, H.; Aidan, A. Produced water treatment using naturally abundant pomegranate peel. Desalin. Water Treat. 2016, 57, 6693-6701. [CrossRef]

119. Jafer, A.S.; Hassan, A.A. Removal of oil content in oilfield produced water using chemically modified kiwi peels as efficient low-cost adsorbent. J. Phys. Conf. Ser. 2019, 1294, 072013. [CrossRef]

120. Alsulaili, A.D.; Fahim, A.M. Oil removal from produced water by agriculture waste adsorbents. Int. J. Environ. Waste Manag. 2020, 25, 12-31. [CrossRef]

121. El-Sayed, M.; Ramzi, M.; Hosny, R.; Fathy, M.; Moghny, T.A. Breakthrough curves of oil adsorption on novel amorphous carbon thin film. Water Sci. Technol. 2016, 73, 2361-2369. [CrossRef] [PubMed]

122. Takeuchi, K.; Kitazawa, H.; Fujishige, M.; Akuzawa, N.; Ortiz-Medina, J.; Morelos-Gomez, A.; Cruz-Silva, R.; Araki, T.; Hayashi, T.; Endo, M. Oil removing properties of exfoliated graphite in actual produced water treatment. J. Water Process. Eng. 2017, 20, 226-231. [CrossRef]

123. Chacra, L.A.; Sabri, M.A.; Ibrahim, T.H.; Khamis, M.; Hamdan, N.; Al-Asheh, S.; AlRefai, M.; Fernandez, C. Application of graphene nanoplatelets and graphene magnetite for the removal of emulsified oil from produced water. J. Environ. Chem. Eng. 2018, 6, 3018-3033. [CrossRef]

124. Okiel, K.; El-Sayed, M.; El-Kady, M.Y. Treatment of oil-water emulsions by adsorption onto activated carbon, bentonite and deposited carbon. Egypt. J. Pet. 2011, 20, 9-15. [CrossRef]

125. Muhammad, I.; El-Nafaty, U.A.; Abdulsalam, S.; Makarfi, Y.I. Removal of oil from oil produced water using eggshell. Civ. Environ. Res. 2012, 2, 52-63.

126. El-Nafaty, U.; Muhammad, I.; Abdulsalam, S. Biosorption and kinetic studies on oil removal from produced water using banana peel. Civ. Environ. Res. 2013, 3, 125-136.

127. El-Nafaty, U.; Abdulsalam Sirajuddeen, I.M. Isotherm studies on oil removal from produced water using mango seed kernel powder as sorbent material. Chem. Process. Eng. Res. 2014, 23, 55-65.

128. Alther, G.R. Organically modified clay removes oil from water. Waste Manag. 1995, 15, 623-628. [CrossRef]

129. Alther, G.R. How to Remove Emulsified Oil from Wastewater with Organoclays. Water Eng. Manag. $2001,148,27-29$.

130. Gabardo, I.T.; Platte, E.B.; Araujo, A.S.; Pulgatti, F.H. Evaluation of Produced Water from Brazilian Offshore Platforms. In Produced Water; Springer: Singapore, 2011; pp. 89-113.

131. Neff, J.; Sauer, T.; Hart, A. Bioaccumulation of Hydrocarbons from Produced Water Discharged to Offshore Waters of the US Gulf of Mexico. In Produced Water; Springer: Singapore, 2011; pp. 441-477.

132. Ayers, R.; Parker, M. Produced Water Waste Management: Technical Report, Canada. 2001. Available online: www.capp.ca (accessed on 6 November 2021).

133. Veil, J.A.; Kimmell, T.A.; Rechner, A.C. Characteristics of Produced Water Discharged to the Gulf of Mexico Hypoxiczone; Argonne National Lab. (ANL): Argonne, IL, USA, 2005.

134. Gallo-Cordova, A.; Silva-Gordillo, M.D.M.; Muñoz, G.A.; Arboleda-Faini, X.; Streitwieser, D.A. Comparison of the adsorption capacity of organic compounds present in produced water with commercially obtained walnut shell and residual biomass. $J$. Environ. Chem. Eng. 2017, 5, 4041-4050. [CrossRef]

135. Ascrizzi, R.; Cioni, P.L.; Amadei, L.; Maccioni, S.; Flamini, G. Geographical patterns of in vivo spontaneously emitted volatile organic compounds in Salvia species. Microchem. J. 2017, 133, 13-21. [CrossRef] 
136. Nasrollahpour, S.; Kebria, D.Y.; Ghavami, M.; Ghasemi-Fare, O. Application of Organically Modified Clay in Removing BTEX from Produced Water. In Geo-Congress 2020: Geo-Systems, Sustainability, Geoenvironmental Engineering, and Unsaturated Soil Mechanics, Minneapolis, Minnesota; American Society of Civil Engineers: Reston, VA, USA, 2020; pp. $275-283$.

137. Costa, A.; Romão, L.; Araújo, B.R.; Lucas, S.; Maciel, S.; Wisniewski, A.; Alexandre, M.D.R. Environmental strategies to remove volatile aromatic fractions (BTEX) from petroleum industry wastewater using biomass. Bioresour. Technol. 2012, 105, 31-39. [CrossRef] [PubMed]

138. Carvalho, M.; Da Motta, M.; Benachour, M.; Sales DC, S.; Abreu, C.A.M. Evaluation of BTEX and phenol removal from aqueous solution by multi-solute adsorption onto smectite organoclay. J. Hazard. Mater. 2012, 239, 95-101. [CrossRef] [PubMed]

139. Egbuchunam, T.; Obi, C.; Okieimen, F.E.; Tihminlioglu, F. Removal of BTEX from aqueous solution using organokaolinite. Int. J. Appl. Environ. Sci. 2016, 11, 505-513.

140. SharmaSarkar, S.; Jaynes, W.F.; Vance, G.F. BTEX Sorption by Montmorillonite Organo-Clays: TMPA, Adam, HDTMA. Water Air Soil Pollut. 2000, 119, 257-273. [CrossRef]

141. Stephenson, M. A Survey of Produced Water Studies. In Produced Water; Springer: Singapore, 1992; pp. 1-11.

142. Bánfalvi, G. Heavy Metals, Trace Elements and Their Cellular Effects. In Cellular Effects of Heavy Metals; Springer: Singapore, 2011; pp. 3-28.

143. Spellman, F.R. Handbook of Water and Wastewater Treatment Plant Operations; CRC Press: Boca Raton, FL, USA, 2013.

144. Kose-Mutlu, B.; Ersahin, M.E.; Ozgun, H.; Kaya, R.; Kinaci, C.; Koyuncu, I. Influence of powdered and granular activated carbon system as a pre-treatment alternative for membrane filtration of produced water. J. Chem. Technol. Biotechnol. 2017, 92, 283-291. [CrossRef]

145. Houcine, M. Solution for heavy metals decontamination in produced water/case study in southern Tunisia. In SPE International Conference on Health, Safety and Environment in Oil and Gas Exploration and Production; Society of Petroleum Engineers: Kuala Lumpur, Malaysia, 2002.

146. Fard, A.K.; Mckay, G.; Chamoun, R.; Rhadfi, T.; Preud'Homme, H.; Atieh, M.A. Barium removal from synthetic natural and produced water using MXene as two dimensional (2-D) nanosheet adsorbent. Chem. Eng. J. 2017, 317, 331-342. [CrossRef]

147. Mon, M.; Bruno, R.; Ferrando-Soria, J.; Armentano, D.; Pardo, E. Metal-organic framework technologies for water remediation: Towards a sustainable ecosystem. J. Mater. Chem. A 2018, 6, 4912-4947. [CrossRef]

148. de Azevedo, A.R.; Marvila, M.T.; Ali, M.; Khan, M.I.; Masood, F.; Vieira, C.M.F. Effect of the addition and processing of glass polishing waste on the durability of geopolymeric mortars. Case Stud. Constr. Mater. 2021, 15, e00662. [CrossRef]

149. Fathy, M.; El-Sayed, M.; Ramzi, M.; Abdelraheem, O.H. Adsorption separation of condensate oil from produced water using ACTF prepared of oil palm leaves by batch and fixed bed techniques. Egypt. J. Pet. 2018, 27, 319-326. [CrossRef]

150. Mahmoud, A.M.; Ibrahim, F.A.; Shaban, S.; Youssef, N.A. Adsorption of heavy metal ion from aqueous solution by nickel oxide nano catalyst prepared by different methods. Egypt. J. Pet. 2015, 24, 27-35. [CrossRef]

151. Gulistan, A.S.; Ibrahim, T.H.; Khamis, M.I.; Elsayed, Y. Application of eggplant peels powder for the removal of oil from produced water. Desalin. Water Treat. 2015, 57, 15724-15732. [CrossRef]

152. Blanchard, G.; Maunaye, M.; Martin, G. Removal of heavy metals from waters by means of natural zeolites. Water Res. 1984, 18, 1501-1507. [CrossRef]

153. Giusti, L. A review of waste management practices and their impact on human health. Waste Manag. 2009, 29, 2227-2239. [CrossRef]

154. Kanoo, P.; Matsuda, R.; Higuchi, M.; Kitagawa, S.; Maji, T.K. New Interpenetrated Copper Coordination Polymer Frameworks having Porous Properties. Chem. Mater. 2009, 21, 5860-5866. [CrossRef]

155. Fujita, M.; Kwon, Y.J.; Washizu, S.; Ogura, K. Preparation, clathration ability, and catalysis of a two-dimensional square network material composed of cadmium (II) and 4, 4'-bipyridine. J. Am. Chem. Soc. 1994, 116, 1151-1152. [CrossRef]

156. Yaghi, O.; Li, G.; Li, H. Selective binding and removal of guests in a microporous metal-organic framework. Nature 1995, 378, 703-706. [CrossRef]

157. Li, J.-R.; Kuppler, R.J.; Zhou, H.-C. Selective gas adsorption and separation in metal-organic frameworks. Chem. Soc. Rev. 2009, 38, 1477-1504. [CrossRef]

158. Ramaswamy, P.; Wong, N.E.; Shimizu, G.K.H. MOFs as proton conductors-challenges and opportunities. Chem. Soc. Rev. 2014, 43, 5913-5932. [CrossRef]

159. Shimizu, G.K.; Taylor, J.M.; Kim, S. Proton conduction with metal-organic frameworks. Science 2013, 341, 354-355. [CrossRef]

160. Campbell, M.G.; Sheberla, D.; Liu, S.F.; Swager, T.M.; Dincă, M. Cu3(hexaiminotriphenylene)2: An Electrically Conductive 2D Metal-Organic Framework for Chemiresistive Sensing. Angew. Chem. Int. Ed. 2015, 54, 4349-4352. [CrossRef]

161. Pardo, E.; Cangussu, D.; Dul, M.-C.; Lescouëzec, R.; Herson, P.; Journaux, Y.; Pedroso, E.F; Pereira, C.; Muñoz, M.C.; Ruiz-García, R.; et al. A Metallacryptand-Based Manganese(II)-Cobalt(II) Ferrimagnet with a Three-Dimensional Honeycomb Open-Framework Architecture. Angew. Chem. Int. Ed. 2008, 47, 4211-4216. [CrossRef] [PubMed]

162. Lim, S.; Buswell, R.; Le, T.; Austin, S.; Gibb, A.; Thorpe, T. Developments in construction-scale additive manufacturing processes. Autom. Constr. 2012, 21, 262-268. [CrossRef]

163. Rubio-Martinez, M.; Avci-Camur, C.; Thornton, A.W.; Imaz, I.; Maspoch, D.; Hill, M.R. New synthetic routes towards MOF production at scale. Chem. Soc. Rev. 2017, 46, 3453-3480. [CrossRef] [PubMed] 
164. Sharifi, S.; Behzadi, S.; Laurent, S.; Forrest, M.L.; Stroeve, P.; Mahmoudi, M. Toxicity of nanomaterials. Chem. Soc. Rev. 2012, 41, 2323-2343. [CrossRef]

165. Zhang, Z.; Lin, Y.H.; Tang, Z.L.; Zhang, J.Y. Nanometer materials \& nanotechnology and their application prospect. J. Mater. Eng. 2000, 3, 42-48.

166. Chaikittisilp, W.; Ariga, K.; Yamauchi, Y. A new family of carbon materials: Synthesis of MOF-derived nanoporous carbons and their promising applications. J. Mater. Chem. A 2013, 1, 14-19. [CrossRef]

167. Lu, G.; Li, S.; Guo, Z.; Farha, O.K.; Hauser, B.G.; Qi, X.; Wang, Y.; Wang, X.; Han, S.; Liu, X.; et al. Imparting functionality to a metal-organic framework material by controlled nanoparticle encapsulation. Nat. Chem. 2012, 4, 310-316. [CrossRef] [PubMed]

168. Tan, J.C.; Cheetham, A.K. Mechanical properties of hybrid inorganic-organic framework materials: Establishing fundamental structure-property relationships. Chem. Soc. Rev. 2011, 40, 1059-1080. [CrossRef]

169. Fediuk, R.S.; Mochalov, A.V.; Pezin, D.N.; Liseitsev, Y.L. Composite Binders for Concretes with Improved Impact Endurance. Inorg. Mater. Appl. Res. 2019, 10, 1177-1184. [CrossRef]

170. Barreto, E.D.S.; Stafanato, K.V.; Marvila, M.T.; de Azevedo, A.R.G.; Ali, M.; Pereira, R.M.L.; Monteiro, S.N. Clay Ceramic Waste as Pozzolan Constituent in Cement for Structural Concrete. Materials 2021, 14, 2917. [CrossRef]

171. Gu, X.; Lu, Z.-H.; Jiang, H.-L.; Akita, T.; Xu, Q. Synergistic Catalysis of Metal-Organic Framework-Immobilized Au-Pd Nanoparticles in Dehydrogenation of Formic Acid for Chemical Hydrogen Storage. J. Am. Chem. Soc. 2011, 133, 11822-11825. [CrossRef]

172. Wu, J.; Xu, J.W.; Liu, W.C.; Yang, S.Z.; Luo, M.M.; Han, Y.Y.; Batten, S.R. Designed metal-organic framework based on metal-organic polyhedron: Drug delivery. Inorg. Chem. Commun. 2016, 71, 32-34. [CrossRef]

173. Song, Z.; Cheng, N.; Lushington, A.; Sun, X. Recent Progress on MOF-Derived Nanomaterials as Advanced Electrocatalysts in Fuel Cells. Catalysts 2016, 6, 116. [CrossRef]

174. Furukawa, H.; Cordova, K.E.; O’Keeffe, M.; Yaghi, O.M. The Chemistry and Applications of Metal-Organic Frameworks. Science 2013, 341, 1230444. [CrossRef]

175. Yang, C.; Kaipa, U.; Mather, Q.Z.; Wang, X.; Nesterov, V.; Venero, A.F.; Omary, M.A. Fluorous Metal-Organic Frameworks with Superior Adsorption and Hydrophobic Properties toward Oil Spill Cleanup and Hydrocarbon Storage. J. Am. Chem. Soc. 2011, 133, 18094-18097. [CrossRef]

176. Chun, J.; Kang, S.; Park, N.; Park, E.J.; Jin, X.; Kim, K.-D.; Seo, H.O.; Lee, S.M.; Kim, H.J.; Kwon, W.H.; et al. Metal-Organic Framework@Microporous Organic Network: Hydrophobic Adsorbents with a Crystalline Inner Porosity. J. Am. Chem. Soc. 2014, 136, 6786-6789. [CrossRef] [PubMed]

177. Xie, L.; Liu, D.; Huang, H.; Yang, Q.; Zhong, C. Efficient capture of nitrobenzene from waste water using metal-organic frameworks. Chem. Eng. J. 2014, 246, 142-149. [CrossRef]

178. Jin, H.; Li, Y.; Liu, X.; Ban, Y.; Peng, Y.; Jiao, W.; Yang, W. Recovery of HMF from aqueous solution by zeolitic imidazolate frameworks. Chem. Eng. Sci. 2015, 124, 170-178. [CrossRef]

179. Seo, Y.S.; Khan, N.A.; Jhung, S.H. Adsorptive removal of methylchlorophenoxypropionic acid from water with a metal-organic framework. Chem. Eng. J. 2015, 270, 22-27. [CrossRef]

180. Ke, F.; Qiu, L.-G.; Yuan, Y.-P.; Peng, F.-M.; Jiang, X.; Xie, A.-J.; Shen, Y.-H.; Zhu, J. Thiol-functionalization of metal-organic framework by a facile coordination-based postsynthetic strategy and enhanced removal of $\mathrm{Hg}^{2+}$ from water. J. Hazard. Mater. 2011, 196, 36-43. [CrossRef]

181. Zhu, B.-J.; Yu, X.-Y.; Jia, Y.; Peng, F.-M.; Sun, B.; Zhang, M.-Y.; Luo, T.; Liu, J.-H.; Huang, X.-J. Iron and 1,3,5-Benzenetricarboxylic Metal-Organic Coordination Polymers Prepared by Solvothermal Method and Their Application in Efficient As(V) Removal from Aqueous Solutions. J. Phys. Chem. C 2012, 116, 8601-8607. [CrossRef]

182. Chowdhury, T.; Zhang, L.; Zhang, J.; Aggarwal, S. Removal of Arsenic(III) from Aqueous Solution Using Metal Organic Framework-Graphene Oxide Nanocomposite. Nanomaterials 2018, 8, 1062. [CrossRef]

183. Qian, X.; Yadian, B.; Wu, R.; Long, Y.; Zhou, K.; Zhu, B.; Huang, Y. Structure stability of metal-organic framework MIL-53 (Al) in aqueous solutions. Int. J. Hydrog. Energy 2013, 38, 16710-16715. [CrossRef]

184. Abbasi, A.; Moradpour, T.; van Hecke, K. A new 3D cobalt (II) metal-organic framework nanostructure for heavy metal adsorption. Inorg. Chim. Acta 2015, 430, 261-267. [CrossRef]

185. Li, Z.-Q.; Yang, J.-C.; Sui, K.-W.; Yin, N. Facile synthesis of metal-organic framework MOF-808 for arsenic removal. Mater. Lett. 2015, 160, 412-414. [CrossRef]

186. Mi, L.; Hou, H.; Song, Z.; Han, H.; Fan, Y. Polymeric Zinc Ferrocenyl Sulfonate as a Molecular Aspirator for the Removal of Toxic Metal Ions. Chem. A Eur. J. 2008, 14, 1814-1821. [CrossRef]

187. Mi, L.; Hou, H.; Song, Z.; Han, H.; Xu, H.; Fan, Y.; Ng, S.-W. Rational Construction of Porous Polymeric Cadmium Ferrocene-1,1'-disulfonates for Transition Metal Ion Exchange and Sorption. Cryst. Growth Des. 2007, 7, 2553-2561. [CrossRef]

188. Das, S.; Kim, H.; Kim, K. Metathesis in single crystal: Complete and reversible exchange of metal ions constituting the frameworks of metal-organic frameworks. J. Am. Chem. Soc. 2009, 131, 3814-3815. [CrossRef]

189. Prasad, T.K.; Hong, D.H.; Suh, M.P. High Gas Sorption and Metal-Ion Exchange of Microporous Metal-Organic Frameworks with Incorporated Imide Groups. Chem. A Eur. J. 2010, 16, 14043-14050. [CrossRef] 
190. Loiseau, T.; Lecroq, L.; Volkringer, C.; Marrot, J.; Férey, G.; Haouas, M.; Taulelle, F.; Bourrelly, S.; Llewellyn, A.P.L.; Latroche, M. MIL-96, a Porous Aluminum Trimesate 3D Structure Constructed from a Hexagonal Network of 18-Membered Rings and 33-Oxo-Centered Trinuclear Units. J. Am. Chem. Soc. 2006, 128, 10223-10230. [CrossRef] [PubMed]

191. Feng, Y.; Yan, G.; Wang, T.; Jia, W.; Zeng, X.; Sperry, J.; Lin, L. Cu 1-Cu 0 bicomponent CuNPs@ ZIF-8 for highly selective hydrogenation of biomass derived 5-hydroxymethylfurfural. Green Chem. 2019, 21, 4319-4323. [CrossRef]

192. Li, C.-Y.; Liu, J.M.; Wang, Z.H.; Lv, S.W.; Zhao, N.; Wang, S. Integration of $\mathrm{Fe}_{3} \mathrm{O}_{4} @$ UiO-66-NH ${ }_{2} @$ MON core-shell structured adsorbents for specific preconcentration and sensitive determination of aflatoxins against complex sample matrix. J. Hazard. Mater. 2020, 384, 121348. [CrossRef]

193. Srinivas, G.; Krungleviciute, V.; Guo, Z.-X.; Yildirim, T. Exceptional CO2capture in a hierarchically porous carbon with simultaneous high surface area and pore volume. Energy Environ. Sci. 2014, 7, 335-342. [CrossRef]

194. Li, P. Groundwater Quality in Western China: Challenges and Paths Forward for Groundwater Quality Research in Western China; Springer: Berlin/Heidelberg, Germany, 2016.

195. Bobbitt, N.S.; Mendonca, M.L.; Howarth, A.J.; Islamoglu, T.; Hupp, J.T.; Farha, O.K.; Snurr, R.Q. Metal-organic frameworks for the removal of toxic industrial chemicals and chemical warfare agents. Chem. Soc. Rev. 2017, 46, 3357-3385. [CrossRef] 